\title{
Dimorphism and evolution of Albarracinites (Ammonoidea, Lower Bajocian) from the Iberian Range (Spain)
}

\author{
Sixto Rafael Fernandez-Lopez* \\ Departamento de Paleontologia, Facultad de Ciencias Geológicas, Universidad Complutense de Madrid, Madrid, Spain
}

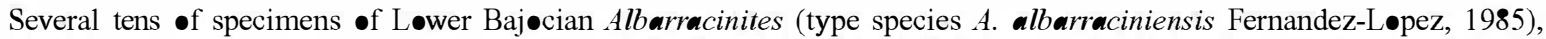
including micrøcøchs and macrøconchs frøm the Iberian Range, have been studied. This ammønite genus ranges in the

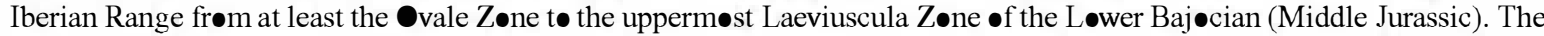

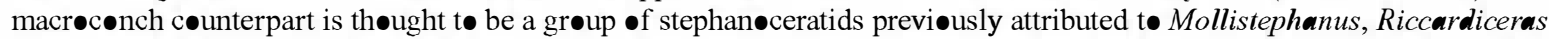

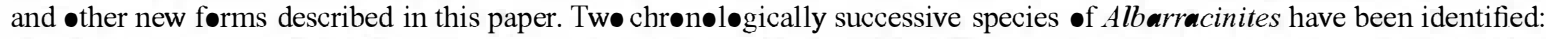

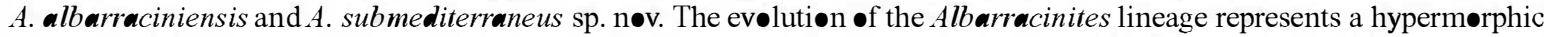

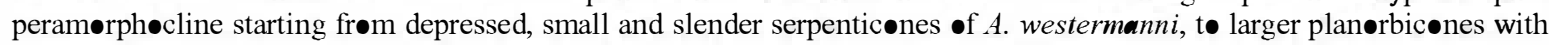

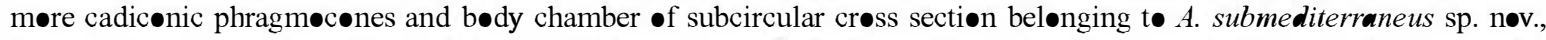
thrøugh A. albarraciniensis Fernandez-Løpez. In contrast, Mollistephanus planulatus (Buckman), M. cockroadensis Chandler

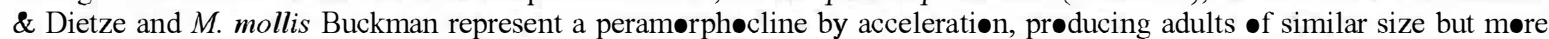
compressed and with increasing ontogenic variation of shell ornament. Albarracinites and Mollistephanus subsequently

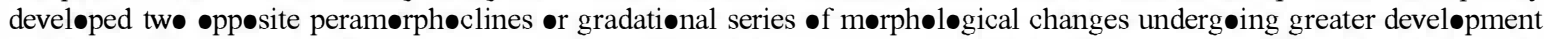

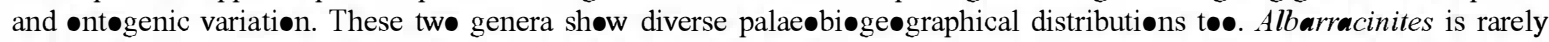
recorded in the Mediterranean and Submediterranean frøm the Discites to the Laeviuscula Zøne, whereas Mollistephanus is

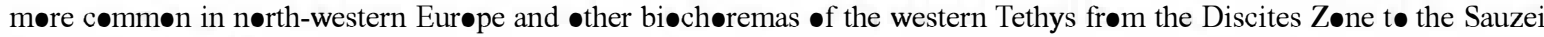

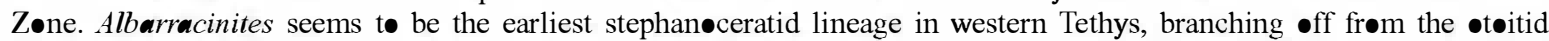

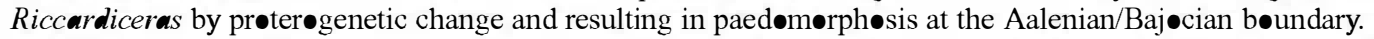

Keywords: ammønites; Albarracinites; Mollistephanus; Submediterranean Prøvince; Nørth-Western Eurøpe Prøvince; Mediterranean Prøvince; Jurassic

\section{Introduction}

Lower Bajocian stephanoceratid ammonites from Europe comprise two genera - Mollistephanus and Albarracinites characterized by potentially dimorphic small and slender serpenticonic and planorbiconic shells, representing macroconchs and microconchs, respectively (FernandezLopez 1985; Chandler \& Dietze 2004). Dimorphism is a special kind of intraspecific variability, well documented in ammonoids, whereby individuals with a similar early ontogeny have polarized adult morphologies probably representing different sexes (Davis et al. 1996). New studies in the Lower Bajocian deposits of the Masada Toyuela area (Sierra de Albarracin, Teruel, Spain, Fig. 1) have yielded a significant number of ammonites in recent years, which have been described by Fernandez-Lopez (1985) from the type locality of Albarracinites albarraciniensis and several nearby sections. Collections made from Masada Toyuela (MT) comprise over 1500 ammonites that are particularly relevant to the interpretation of the
Albarracinites beds belonging to the Ovale and Laeviuscula zones. Albarracinites is relatively common in some levels but still represents less than $5 \%$ of specimens.

The present work is concerned with the systematic position of the genus Albarracinites, which has been monospecific since its erection 25 years ago. A new species of Albarracinites is identified among the specimens recently collected in the Iberian Range, and new biochronological and palaeobiological results about the phyletic origination of Stephanoceratidae are given.

\section{Palaeoenvironmental and palaeobiogeographical setting}

Aalenian and lowermost Bajocian deposits of the Iberian Range are commonly represented by condensed sections containing stratigraphical discontinuities in the lower part of the El Pedregal Formation (Chelva Group, Gomez \& Fernandez-Lopez 2006). The Albarracinites beds 


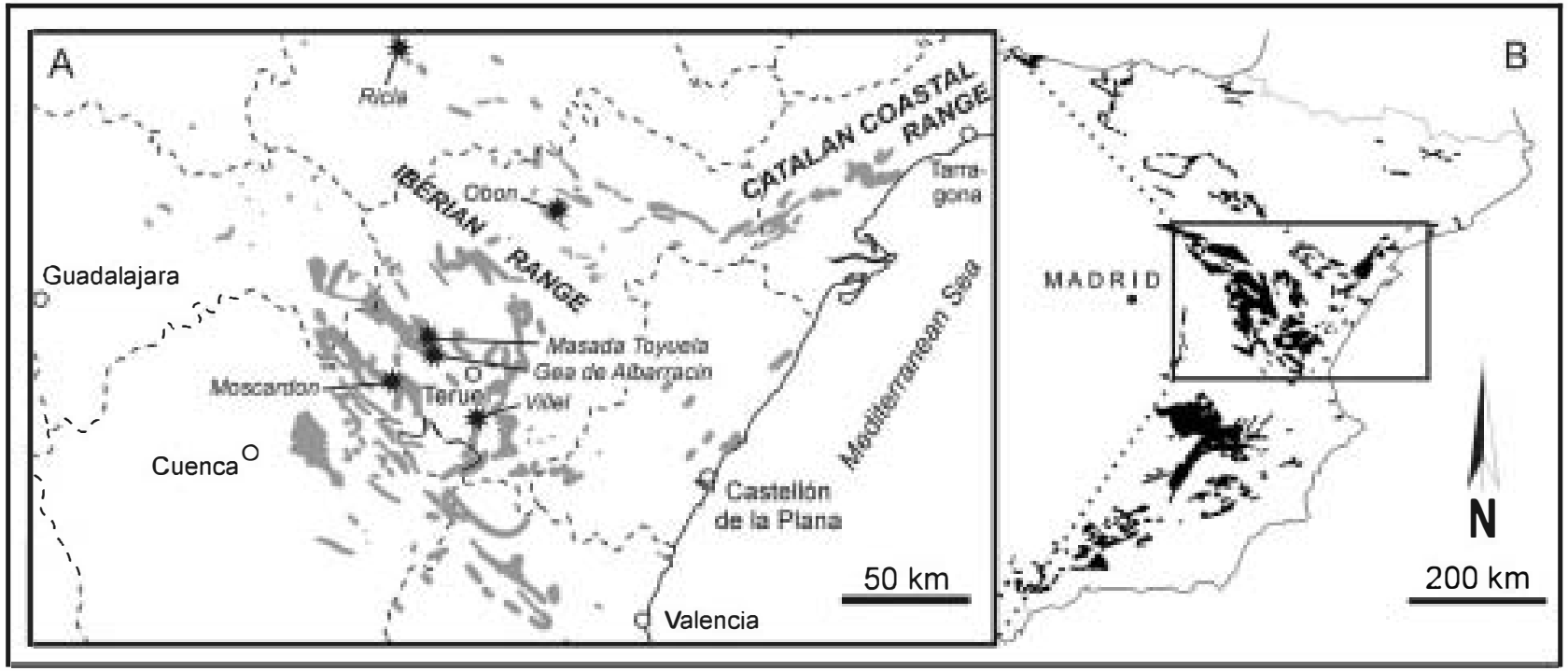

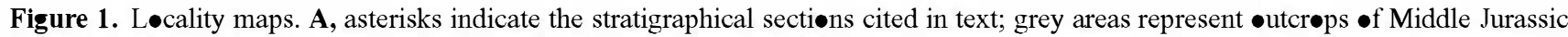

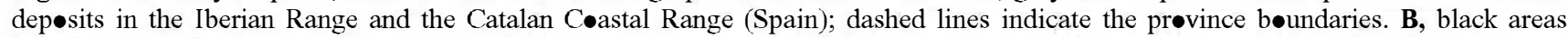
represent Jurassic •utcrøps.

correspond to condensed sections, compøsed of decimetric or centimetric, expanded-deposit intervals, stacked and showing an overall thinning upward, which constitute a deepening sequence developed in shallow-water, openmarine, carbonate environments of the External Castilian Platform during the Ovale and Laeviuscula biochrons (Fig. 2). Taphonomic analyses corroborate the develøpment of an incipient-deepening phase, which represents the first episøde of a deepening half-cycle of third order in the Albarracin area within the Castilian Platform (Fernandez-Løpez \& Gømez 2004; Fernandez-Løpez 2011).

In a general palaeobioge graphical context, the biødispersal of individuals can lead to their settlement in new areas if suitable ecological conditions are present, and can give rise to population migration with ontogenic and/or sexual segregation. Populations remaining in a new area may give rise to $\bullet f f s p r i n g$, leading to sustained cølonization. However, the individuals or populations that live and mate in an area may be residents or migrants (Cecca 2002).

To separate elements or assemblages produced by resident or migrant populations from elements or assemblages preduced by necrokinesis and post-mortem transport, it is useful to distinguish between demic and nøn-demic taxa. The former are identified from fossils found in the living area, and the latter from fossils found outside the living area (Fig. 3A). In turn, among demic taxa three categories have been distinguished: eudemic (recorded in their living and breeding area), miodemic (recorded in a living area without breeding, and present there as a result of active biedispersal), and parademic (recorded in a living area without breeding and present there as a result of $\bullet$ ccasional passive biedispersal).
In ammønite palaeøbiogeography, the crucial dispersal can be by taphonomic mødifications such as the sørting of shell size distribution and $\bullet$ togenic stages due to prøcesses -f necrokinesis and pøst-mortem transport. Macrøconchs (abbreviated as M) and microconchs (abbreviated as m) -f ammonites represent distinct taphonomic groups, or taphons, due to their structural and behaviour differences (Fernandez-Lopez 2006, 2007). Taphons are integrated by local taphonic populations, which can be preserved in particular environments. In order to describe and analyse ammonite fossil assemblages, three types of taphonic pøpulations can be identified (Fig. 3B). A type-1 taphønic population comprises a monospecific group of shells, with unimedal size-frequency distributions of positive asymmetry, dominant juveniles, adults virtually absent, and dimorphism well represented. A type-2 taphonic population comprises monospecific or polyspecific shells, with unimødal or pølymødal, normal distribution of size-frequencies, pre-adults or adults dominant, very scarce juveniles, and microconchs usually in low proportions. A taphonic population of type 3 comprises monospecific or pølyspecific shells, with unimødal or pølymødal size-frequency distributions of negative asymmetry, adults dominant, juveniles absent, and dimorphism poorly represented. As a result of taphonomic dispersal, type-1 taphonic populations are indicative of eudemic taxa, whereas type- 3 taphonic populations are indicative of ademic taxa. Mønospecific and dimorphic taphonic populations of type 2 , with pre-adults present, are characteristic of miedemic taxa, whereas monomorphic taphonic populations of type 2, with adults dominant, are characteristic of parademic taxa. 


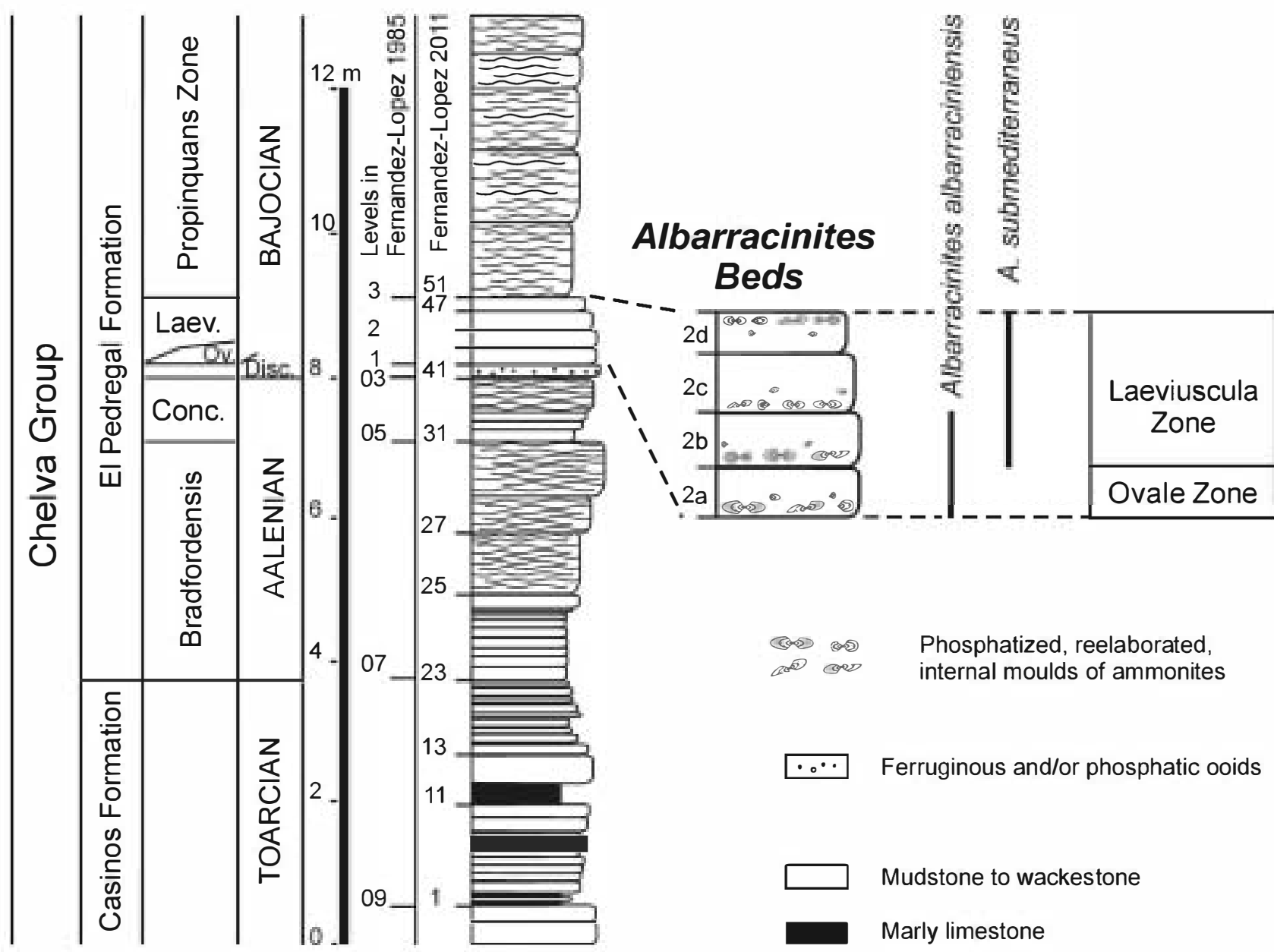

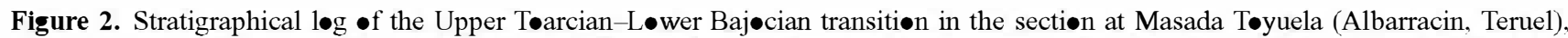

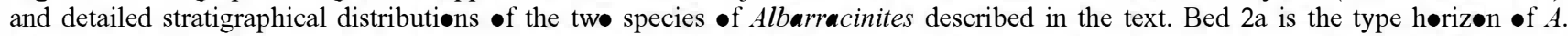

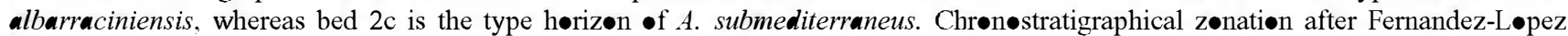
(2012).

Aalenian and Early Bajøcian ammønite populations dominated by juveniles and indicative of eudemic taxa (i.e. in their breeding area, according to Callomøn 1985) were absent in the Castilian Platform. Most recorded ammønite genera are represented by pølyspecific groups of adult shells, generally macrøconchs, produced by ademic or parademic taxa that arrived at their present location by regional necrøkinesis or passive biodispersal, respectively. However, the exceptional occurrence of monøspecific pøpulations, including macroconchs and micreconchs such as in Hebetoxyites (Fernandez-Løpez 2012, fig. 2), or even with predominance of microconchs as in Albarracinites (Fig. 4; Fernandez-Løpez 2011, fig. 9), lacking juveniles but dominated by pre-adults, suggests autochthonous biogenic prøduction $\bullet$ shells by miødemic taxa (i.e. in an area $\bullet c c u-$ pied by active biodispersal, but where breeding does not occur), after immigration in the eastern Iberian platform system. Twø regional biø-events contrelled by changes
- f relative sea level in the Castilian Platform have been identified: (1) regional appearance of immigrant ammonite taxa, such as Hebetoxyites and Albarracinites, at the Discites/Ovale transition; and (2) regional disappearance -f these miødemic ammonite taxa at the Laeviuscula/Sauzei transition (Fernandez-Lopez 2012).

\section{Systematic palaeontology}

Class Cephalopoda Cuvier, 1798

Subclass Ammonoidea von Zittel, 1884

Order Ammonitida Fischer, 1882

Superfamily Stephanoceratoidea Neumayr, 1875

Family Stephanoceratidae Neumayr, 1875

Remarks. The superfamily Stephanoceratoidea Neumayr, 1875 branched from Aalenian Erycitidae Spath, 1927 of the 


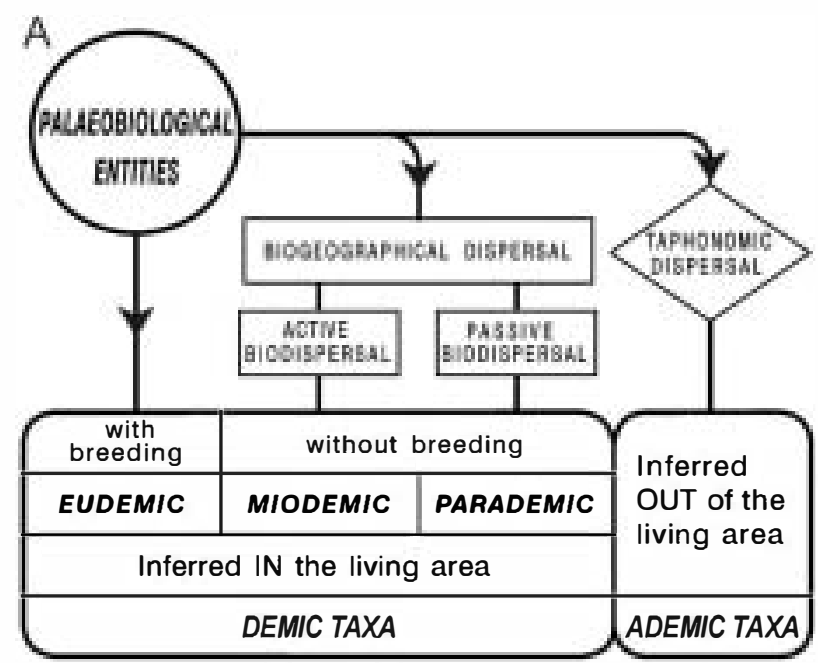

B

\begin{tabular}{|c|c|c|c|}
\hline \multicolumn{4}{|c|}{ TAPHONIC POPULATIONS: } \\
\hline TYPE-1 & \multicolumn{2}{|c|}{ TYPE-2 } & TYPE-3 \\
$\begin{array}{c}\text { positive } \\
\text { asymmetry } \\
\text { dominant } \\
\text { juveniles }\end{array}$ & $\begin{array}{c}\text { normal } \\
\text { distribution } \\
\text { present } \\
\text { pre-adults }\end{array}$ & $\begin{array}{c}\text { normal } \\
\text { distribution } \\
\text { dominant } \\
\text { adults }\end{array}$ & $\begin{array}{c}\text { negative } \\
\text { asymmetry } \\
\text { dominant } \\
\text { adults }\end{array}$ \\
\hline $\begin{array}{c}\text { dimorphic } \\
\text { monospecific } \\
\text { genera }\end{array}$ & $\begin{array}{c}\text { dimorphic } \\
\text { monospecific } \\
\text { genera }\end{array}$ & $\begin{array}{c}\text { monomorphic } \\
\text { or polyspecific }\end{array}$ & $\begin{array}{c}\text { monomorphic } \\
\text { generas } \\
\text { genera }\end{array}$ \\
\hline
\end{tabular}

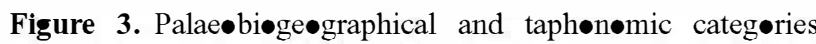

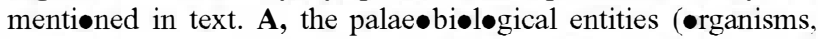
pøpulatiøns $\bullet$ species) are demic when their føssils are recørded in their living area. Cønversely, they are ademic species ( $\bullet$ taxa) when they are recorded $\bullet$ inferred $\bullet$ utside $\bullet$ their living area. Demic species may be recorded in their breeding area (eudemic), in an area n๑rmally $\bullet$ ccupied by active biødispersal but where they

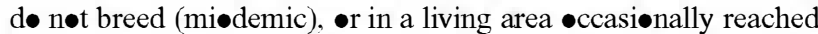
by passive biødispersal (parademic) (according to Fernandez-

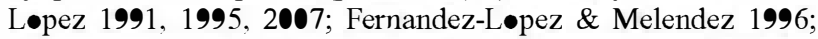

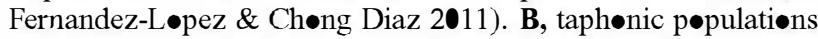
- f type 1 are indicative of sustained colønization by eudemic

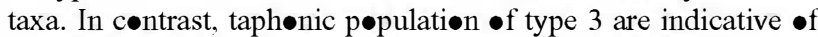
ademic taxa. Taphønic pøpulations $\bullet$ fype 2, displaying interme-

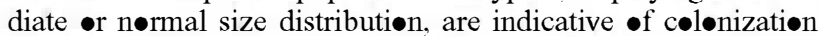

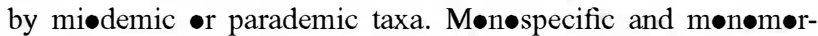

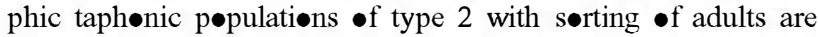
characteristic of parademic taxa, whereas møn

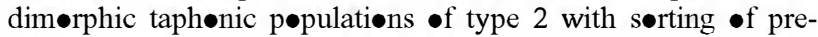
adults are characteristic $\bullet$ miødemic taxa.

superfamily Hammatoceratøidea Schindewelf, 1964 that gave rise to Otoitidae Mascke, 1907, which includes taxa such as Docidoceras [M]-Trilobiticeras [m], Riccardiceras $[\mathrm{M}$ and $\mathrm{m}]$ and Westermannites $[\mathrm{M}]$. At the Aalenian/Bajøcian transition, in turn, Otoitidae were the source -f Stephanoceratidae Neumayr, 1875, including Mollistephanus [M and $\mathrm{m}$ ] and Albarracinites [M and $\mathrm{m}$ ], according to the results and conclusions below (cf. Arkell
1952; Westermann 1956, 1964a, 1993, 1995; Arkell et al. 1957; Geczy 1966; Westermann \& Riccardi 1979; Callomøn 1981; Tintant \& Mouterde 1981; Pavia 1983; Sandøval 1983; Fernandez-Løpez 1985; Page 1996, 2008; Sandoval et al. 2000; Dietze et al. 2001, 2010; Chandler \& Dietze 2004; Møyne \& Neige 2004; ○'Dogherty et al. 2006; Shevyrev 2006; Howarth 2013).

The morphological terms used herein føllow the Glossary -f the Treatise on Invertebrate Paleontology (Arkell et al. 1957) and other terms presented by Westermann (1996, 2005). The family Stephanoceratidae is characterized by serpenticones, planorbicones and cadicønes, with ribbing ventrally uninterrupted, and egressive coiling at maturity, differentiated int॰ dimørphic grøups: (1) micrøcønchs [m] with lateral lappets and short body chambers ribbed to the end; and (2) macroconchs [M] with simple apertures and long bødy chambers (near to, or longer than, $360^{\circ}$ ) that are smooth or distantly ribbed. The septal suture is complex, with deeply divided lateral saddles and retracted umbilical lobes in the macroconchs, but slightly simplified in the micreconchs. Lateral saddle $\mathrm{E} / \mathrm{L}$ is asymmetrical and higher than $\mathrm{L} / \mathrm{U} 2$.

Genus Albarracinites Fernandez-Lopez, 1985 [m and M]

Type species. Albarracinites albarraciniensis FernandezLøpez, 1985, Løwer Bajøcian, Iberian Range, Spain.

Diagnosis. Micrøconch $(\operatorname{Dmax}=15-35 \mathrm{~mm})$ and macreconch (Dmax $=50-170 \mathrm{~mm}$ ) stephanoceratids $\bullet$ small to medium size (Figs 5-10). Macroconchs bear a simple aperture, with trumpet-like expansion of the adult peristome. Microconchs have a peristome with lateral lappets. Adult bødy chamber, with eccentric coiling, is typically over a half whorl in micreconchs and a little over one whorl in macroconchs. The coiling is planulate, more involute on the inner whorls (U/D $=36-50 \%)$ and becomes more evolute towards the adult aperture (Fig. 5). The whorl section is @val and depressed on the inner whorls (W/H $=200-160 \%)$, rather cadiconic in appearance ( $\mathrm{W} / \mathrm{D}=50-35 \%)$, and becomes more rounded and subcircular $\bullet$ the outer whorls $(\mathrm{W} / \mathrm{H}=140-100 \%)$. Ribbing is straight to slightly sinuøus, blunt and persists throughout ontogeny. Bifurcate or trifurcate ribs show a rursiradiate tendency, particularly in the inner and intermediate whorls. Secondary ribs are uninterrupted $\bullet$ the venter, becoming blunter, $\bullet$ variable strength and spacing, in the outer whorls. Tubercles can be present at furcation points. Lateral saddle $\mathrm{E} / \mathrm{L}$ is high and narrow. The lateral lobe is shorter than, or similar to, the exter-

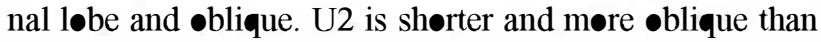
L.

Remarks. According to this new diagnosis of the genus, Albarracinites $[\mathrm{m}$ and $\mathrm{M}]$ differs from Mollistephanus Buckman, 1922 [M and $\mathrm{m}$ ] (type species M. mollis Buckman, 1902 [M] in 1909-1930, TA-IV, pl. 344; 

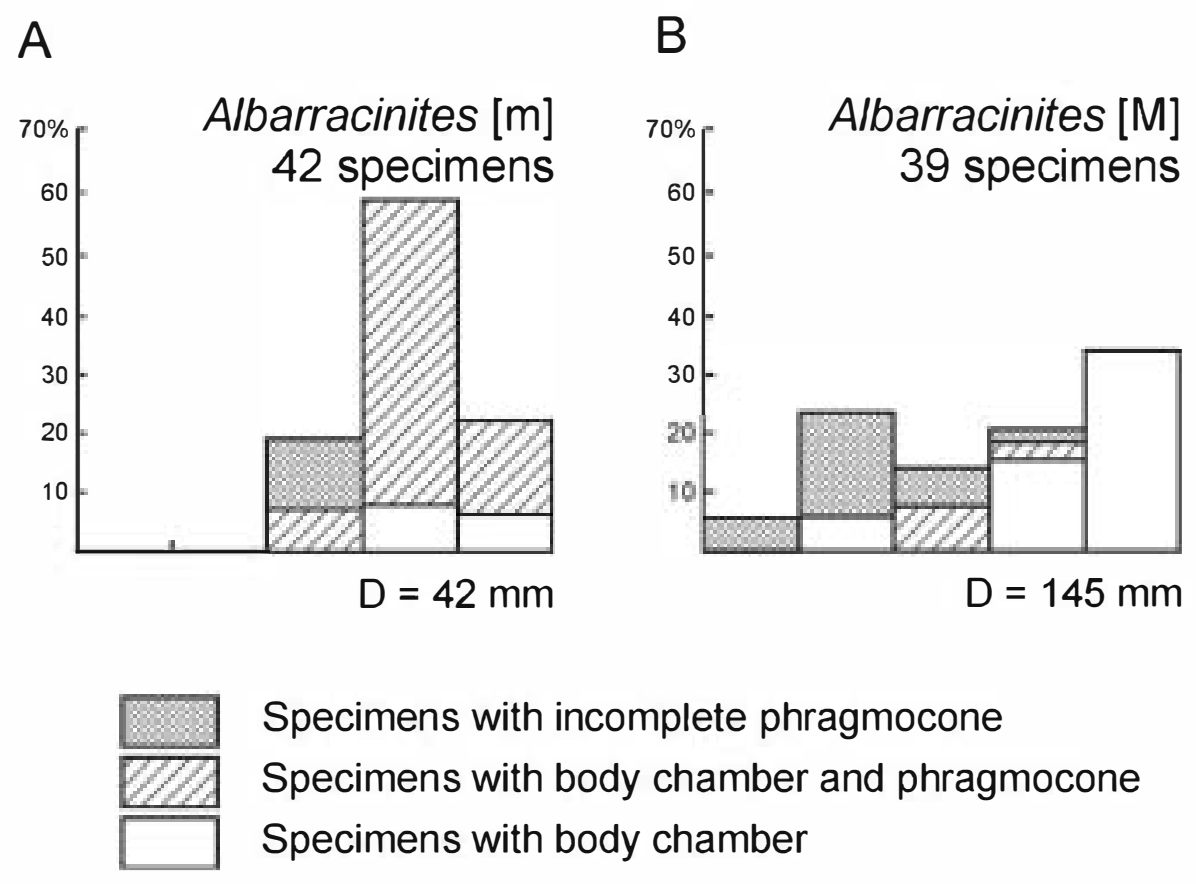

\section{Specimens with incomplete phragmocone \\ Specimens with body chamber and phragmocone \\ Specimens with body chamber}

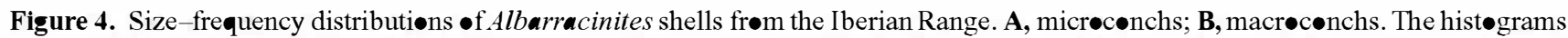

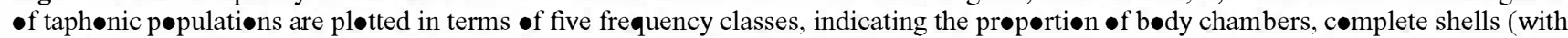

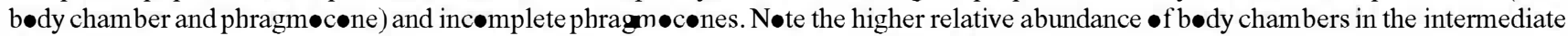

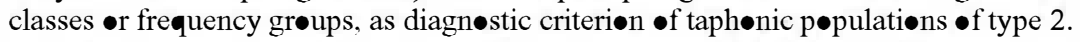

hølotype refigured by Chandler \& Dietze 2004, fig. 4.1a, b, and Rulleau 2011, pl. 48, fig. 2a, b; allegedly from Coombe, probably Sandford Lane, near Sherborne, Dorset, England, Trigønalis Subzone, Laeviuscula Zone) by less serpenticonic coiling and a less compressed section on the outer whorls (Fig. 11A-F). The ribbing is blunter, with a less pronounced ventral furcation point. The secondary ribs of variable strength and spacing in the outer whorls of the Albarracinites micreconchs are a further difference.

Other minute Early Bajocian stephanoceratids from the Mediterran-Caucasian Subrealm, such as Phaulostephanus Buckman, 1927 [M and $\mathrm{m}$ ] (type species P. paululus Buckman, 1927 [M] in 1909-1930, TA-VII, pl. 754; holotype from Clatcombe, near Sherbørne, Dorset, Rømani Subzone, Humphriesianum Zøne) show more serpenticønic cøiling, with secøndaries møre prøverse and a shorter bødy chamber than Albarracinites (cf. Galacz 2012).

Skirroceras Mascke, 1907 [M] (type species 'Ammonites Humphriesianus macer' Quenstedt, 1886, p. 528, pl. 65, fig. 11; lectotype designed by Buckman, 1921, pl. 248 and refigured by Schlegelmilch 1985, pl. 23, fig. 2; from the Humphriesianum-@olith, Swabia, Germany, Lower Bajøcian) and Stephanoceras Waagen, 1869 [M] (type species 'Ammonites Humphriesianus' J. de C. Sowerby, 1825 in Sowerby \& Sowerby, 1812-1846, pl. 500; hølotype repreduced as a phot graph by Fallot \& Blanchet 1923, pl. 13, fig. 1; from Sherbørne, Dorset, Inferiør @olite, Lower
Bajøcian) display more complex suture lines, with subparallel, deep and narrow lateral lobes and strøngly retracted suspensive lobes. Bøth genera are longidøme, the body chamber surpassing $450^{\circ}$ and reaching $750^{\circ}$ in Skirroceras, whereas it varies from $360^{\circ}$ to $450^{\circ}$ in Stephanoceras (Fernandez-Lopez 1985; Westermann 2005). The microconch counterpart of Skirroceras, Epalxites Mascke, 1907 [m] (type species Ammonites contractus anceps Quenstedt, 1886, p. 521, pl. 64, fig. 20; hølotype refigured by Westermann 1954, pl. 28, fig. 1; from Lauffen, Germany, Døgger- $\delta$, probably Sauzei Zøne) and the microconch counterpart of Stephanoceras, Itinsaites McLearn, 1927 [m] (type species Itinsaites itinsae McLearn, 1927, p. 73, hølotype figured in pl. 1, fig. 7; refigured by Westermann 1954, pl. 26, fig. 5; from the lower Yakoun Formation, south Balch Island, Skidegate Inlet, Queen Charlotte Islands, Canada, in the Chondroceras oblatum Zone, probably Humphriesianum Zone, after Hall \& Westermann 1980, p. 41 and Hall et al. 1991, p. 144) display sharper ribbing than Albarracinites [m]. Normannites Munier-Chalmas, 1892 [m] (type species Normannites orbignyi Bucleman, 1908 , p. 146,1927 , pl. 734 ; neotype designated by Westermann 1954, p. 136; frøm Clatcombe, Sherborne, Dørset, Humphriesianum Zøne, Løwer Bajøcian) alsø shows sharper ribbing than Albarracinites $[\mathrm{m}]$ and represents the dimorph of Teloceras Mascke,1907 [M] (type species Ammonites blagdeni J. Sowerby, 1818 in Sowerby \& Sowerby, 1812-1846, p. 231, pl. 201; hølotype from Dorset, 
- 0 Albarracinites submediterraneus [ $\mathrm{m}$ and $\mathrm{M}$ ]

$\Delta \quad \Delta$ Albarracinites albarraciniensis [ $\mathrm{m}$ and $\mathrm{M}$ ]

A

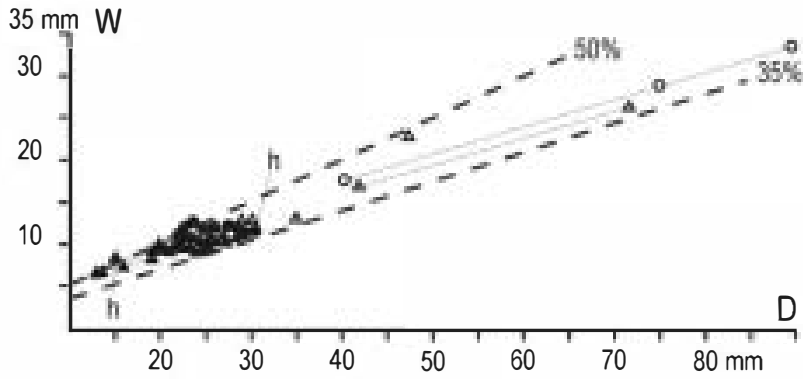

B

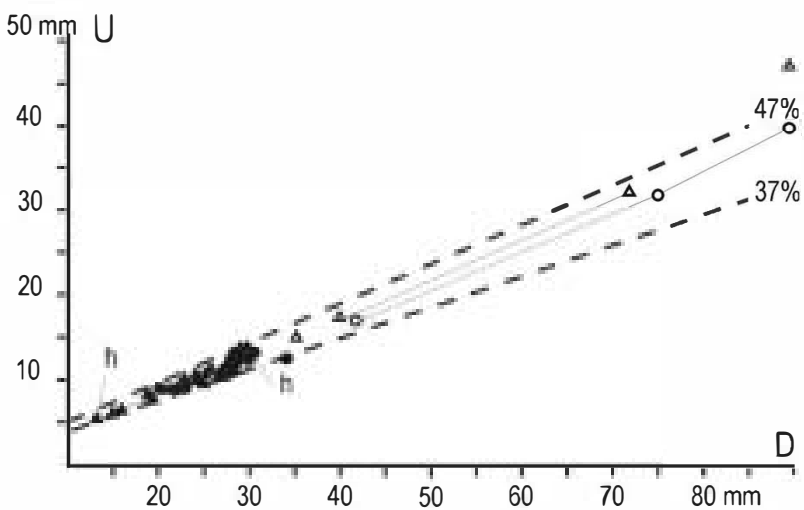

C
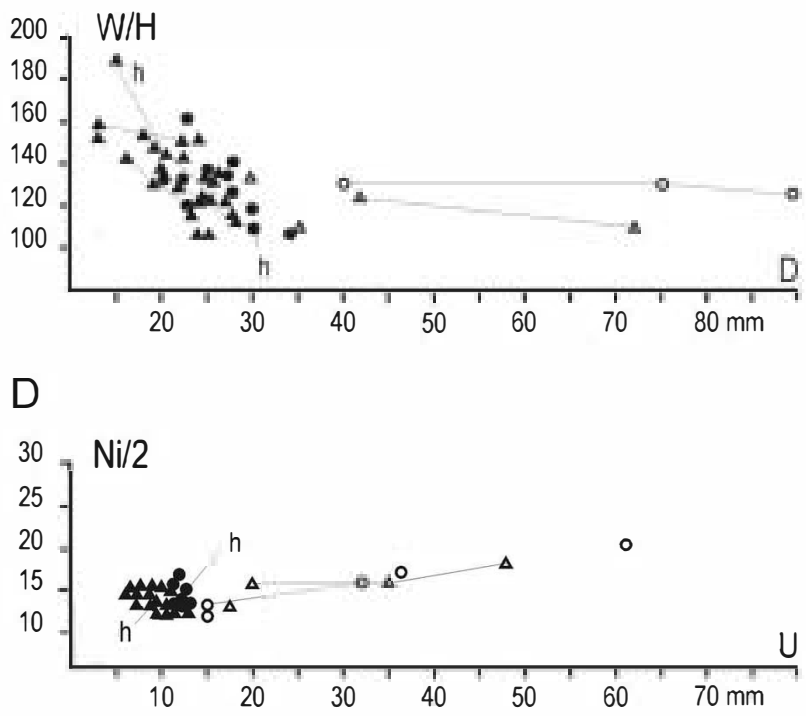

Figure 5. Pløts of measurements of Albarracinites frøm the Iberian Range. A, whørl width (W) versus shell diameter (D); B, umbilical diameter (U) versus shell diameter (D); C, whørl width/whørl height rati• $(\mathrm{W} / \mathrm{H})$ versus shell diameter $(\mathrm{D})$; D, internal ribs per half whorl $(\mathrm{Ni} / 2)$ versus umbilical diameter $(\mathrm{U})$. Abbreviatiøns: m, micrønch; M, macrønch; h, høløtype. uppermøst Humphriesianum Zøne, Løwer Bajøcian); bøth - these are coronate cadicones of greater size.

Kumatostephanus Buckman, 1922 [M] (type species Kumatostephanus kumaterus Buckman, 1922, pl. 345; hølotype refigured by Rulleau 2011, pl. 48, fig. 1a, b; from Søuth Main Røad Quarry, Dundry, faunal horizon Bj11a, Sauzei Zone after Chandler et al. 2006) is more coarsely ribbed and has a more simple suture line, with a broad lateral lobe and a suspen-sive lobe not strongly retracted. Gerzenites Westermann, 1954 [m] (type species Normannites (Gerzenites) mugosus Westermann, 1954, p. 231, holotype figured in pl. 19, fig. 4; from the OtoitesSchichten, Gerzen, Germany, Sauzei Zøne), the microconch counterpart of Kumatostephanus, shows sharper ribbing and more proverse secondaries than Albarracinites $[\mathrm{m}]$.

Some small and slender stephanoceratids from the East Pacific Subrealm, such as Parabigøtites Imlay, 1961 [M] (type species $P$. crassicostatus Imlay, 1961, p. 473, pl. 64, figs 8, 10, holotype refigured by Imlay 1964 , p. 54, pl. 29, figs 14, 15, and Rulleau 2011, pl. 70, fig. 1; from the Kialagvik Formation, Alaska Peninsula, upper Sauzei Zøne) and Frebøldites Taylor, 1988 [M] (type species $F$. bifurcatus Taylor, 1988, p. 136, holotype 'Stephanoceras (Skirroceras) cf. dolichøechus' of Imlay 1973, p. 88, pl. 45 , fig. 8, refigured by Rulleau 2011, pl. 58, fig. 4; from Vigrass' locality 162, Weberg Member, Snowshøe Formation, Oregøn, USA, Sauzei Zøne and topøtypes pøssibly alsø recorded in the Laeviuscula Zone) show more planorbicønic and evolute shells than Albarracinites, with subparallel and deeper lateral lobe.

Otøitids comprise cadicønes and serpenticønes with thick primary ribs, umbilical egression and flattening $\bullet$ the adult body chamber, as in Docidoceras, Riccardiceras and Westermannites. Docidoceras Buckman, 1919 [M] (type species D. cylindroides Buckman, 1919, pl. 133A; from Bradford Abbas, Sherbørne, Dørset, Discites Zøne) differs from Albarracinites [M] by having a shorter, more depressed and contracted adult body chamber, and more complex septal suture with the lateral lobe subparallel and deeper than the external lobe. Trilobiticeras Buckman, 1919 [m] (type species T. trilobitoides Bucleman, 1919, pl. 140; from Bradford Abbas, Sherbørne, Dørset, Discites

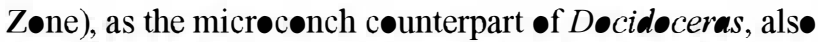
shows more cadiconic coiling and shorter primaries than Albarracinites $[\mathrm{m}]$, with $\mathrm{U} 2$ in an outer position relative to the lateral tubercles.

Riccardiceras Westermann, 1995 [M and m] (type species Coeloceras longalvum Vacek, 1886 [M], p. 99, pl. 17, figs 1,2 , lectotype reproduced as a photograph by Westermann 1964a, p. 48, pl. 6, figs 1, 2, and Dietze et $\boldsymbol{a l}$. 2001, p. 9, fig. 6; from the San Vigilio Oolite Formation, Cap San Vigilie, Lake Garda, Italy, Upper Aalenian after Callomøn et al. 1994), lacking a corønate-cadiconic juvenile stage, comprises serpenticones of larger adult size than 

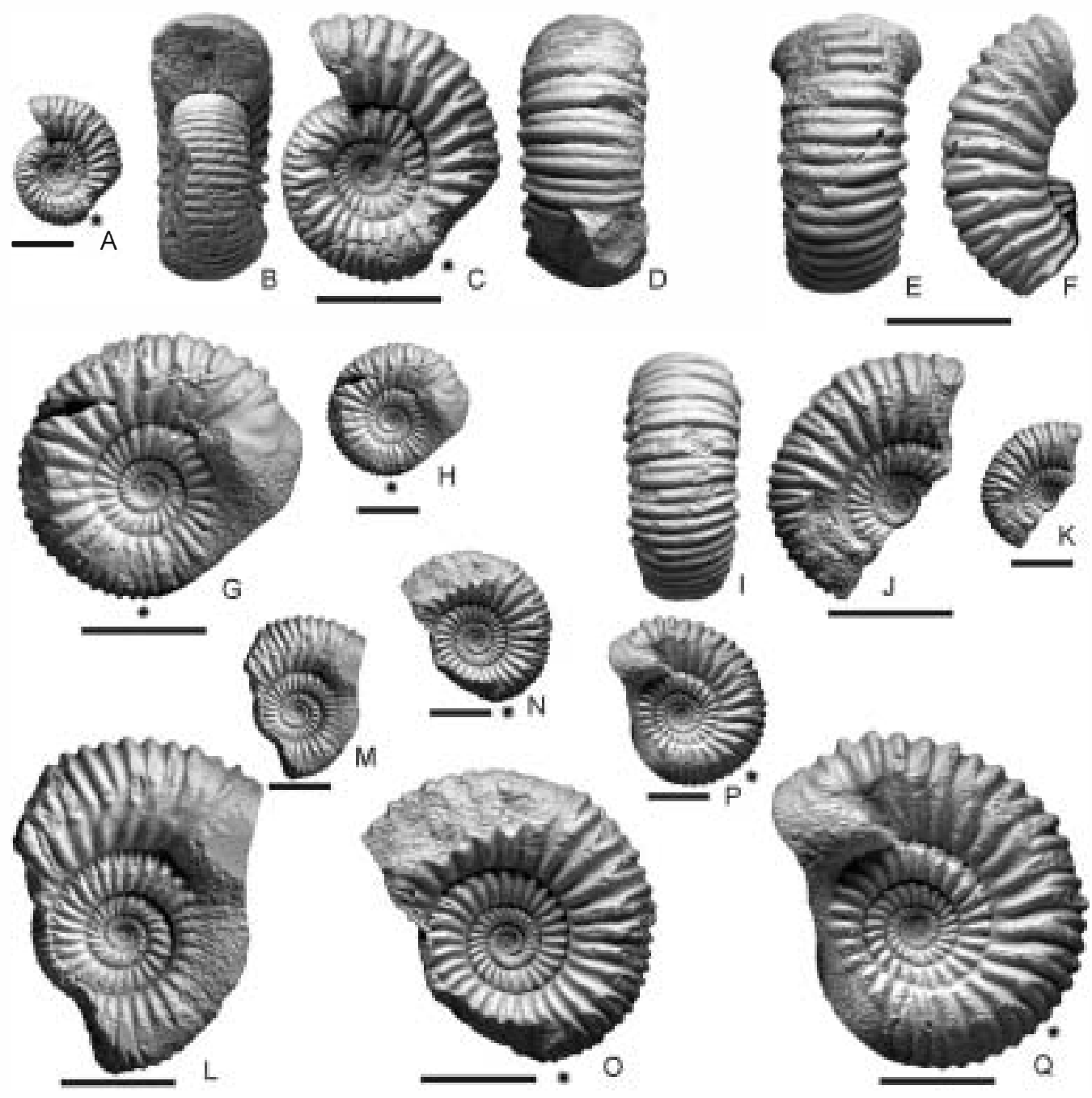

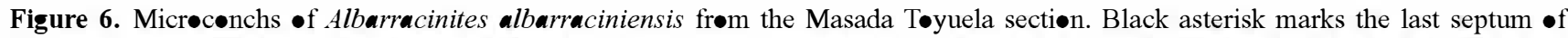

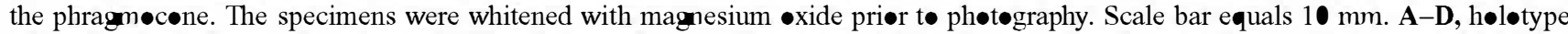

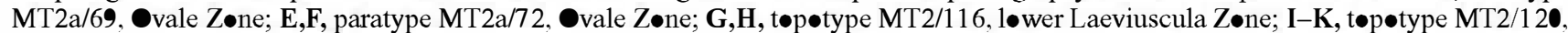

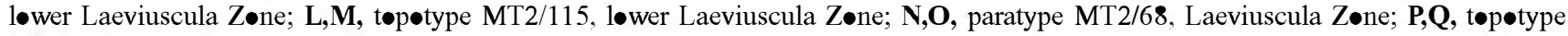
MT2/117, løwer Laeviuscula Zøne.

Albarracinites $[\mathrm{M}]$. Westermannites Dietze et al., $2001[\mathrm{M}]$ (type species Coeloceras limatum Pompeckj, 1897 [M], pl. 31, fig. 5, holotype reproduced as a photograph by Dietze et al. 2001, p. 11, fig. 7; from Kessik-tash near Ankara, Turkey, Lower Bajøcian), with a corønate-cadiconic juvenile stage, can alse reach larger adult sizes than Albarracinites $[\mathrm{M}]$. Riccardiceras and Westermannites display a subparallel lateral lobe, longer than the external lobe, instead $\bullet$ f the oblique and short lateral lobe seen in Albarracinites.

Distribution. The known range of Albarracinites is restricted to the Lower Bajøcian, with acme in the Ovale and Laeviuscula zones, in several areas of western Tethys. Forms of this genus have been identified from the Iberian Range (Fernandez-Lopez 1985; Fernandez-Lopez \&
Aurell 1988), Basque-Cantabrian Basin (Fernandez-Løpez et al. 1988b), Lusitanian Basin (Fernandez-Lopez et al. 1989), Betic Basin (Sandoval et al. 2000, 2001, 2002) and Morecc (Sadki 1994, 1996). Amøng the representatives -f Albarracinites from the Iberian Range, two species have been distinguished in the Ovale and Laeviuscula zones: A. albarraciniensis Fernandez-Lopez and $A$. submediterraneus sp. nov.

Albarracinites albarraciniensis Fernandez-Løpez, 1985 [m and $\mathrm{M}]$

(Figs 6A-Q, 7D-J, 8A, 9C-G)

1985 Albarracinites albarraciniensis Fernandez-Lopez: 301, pl. 36, figs 1 (hølotype), 2, 3 (paratypes), 33, 34. 1985 M॰llistephanus sp. nov. 3.; Fernandez-L॰pez: 251, pl. 20, figs 13, 14, 27D-F. 


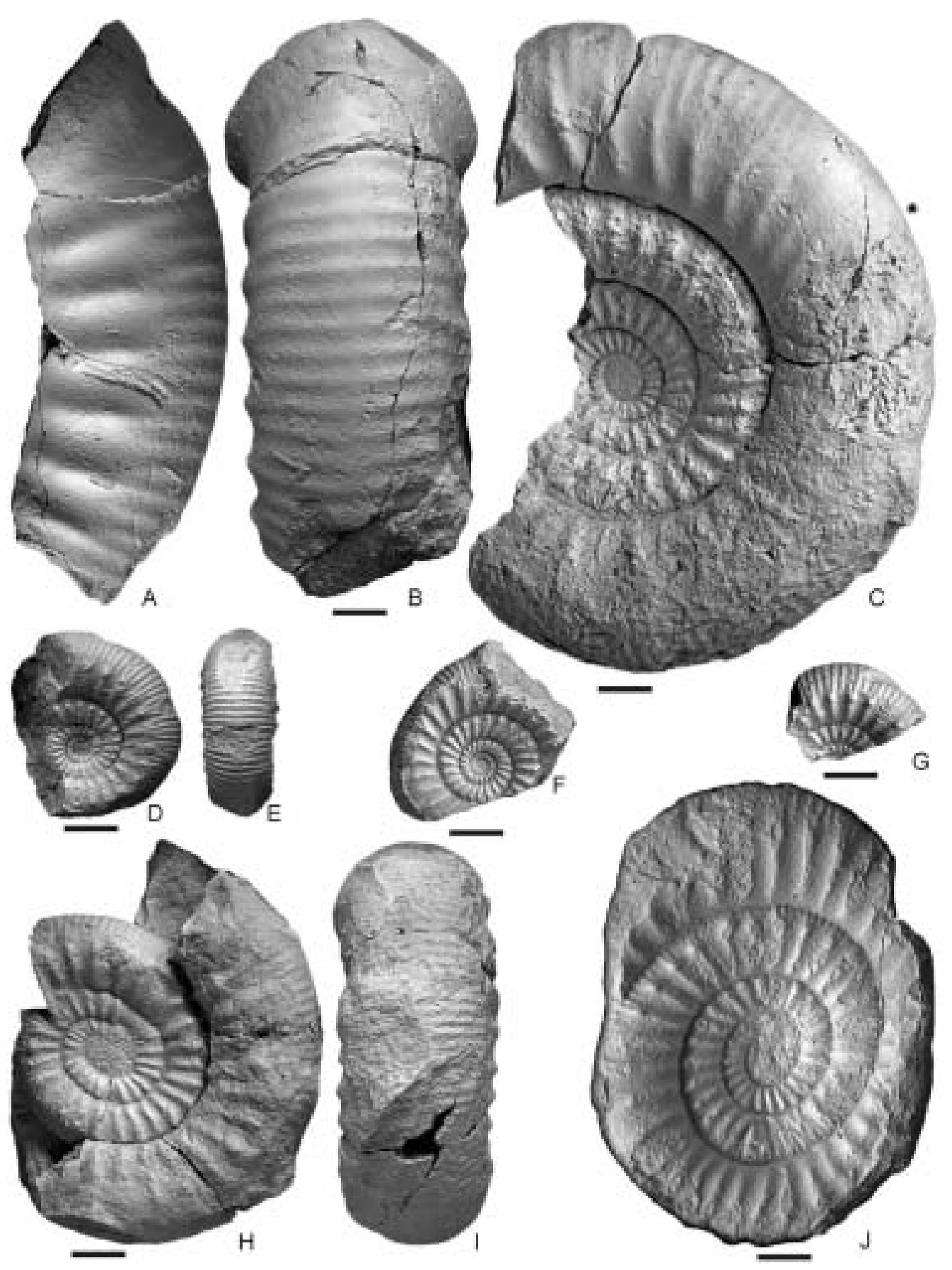

Figure 7. Macrøconchs of Albarracinites frøm the Masada Tøyuela sectiøn. Laeviuscula Zøne. Black asterisk marks the last septum

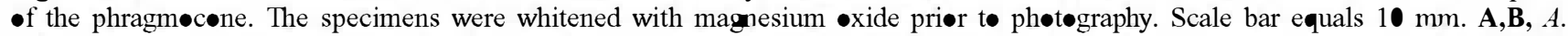
submediterraneus, paratype MT2/67; C, A. submediterraneus, paratype MT2c/143; D,E, A. albarraciniensis, tøp॰type MT2/144; F,

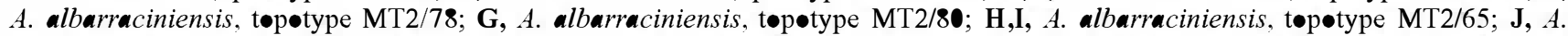
albarraciniensis, top॰type MT2/77.

1988 Albarracinites albarracinensis Fernandez Løpez;

Gomez-Alba: 426, pl. 210, fig. 7 (hølıtype).

Diagnosis. Micreconch (Dmax 20-30 mm) and macrøconch (Dmax 150-160 mm). Albarracinites planorbicones -f relatively small size.
Etymology. From its eccurrence in the Albarracin area (Teruel, Spain).

Material. More than 28 specimens from three localities, Ovale and lowermost Laeviuscula zones: 24 specimens from Masada Toyuela (Ovale Zøne: MT2a/69, 72; 

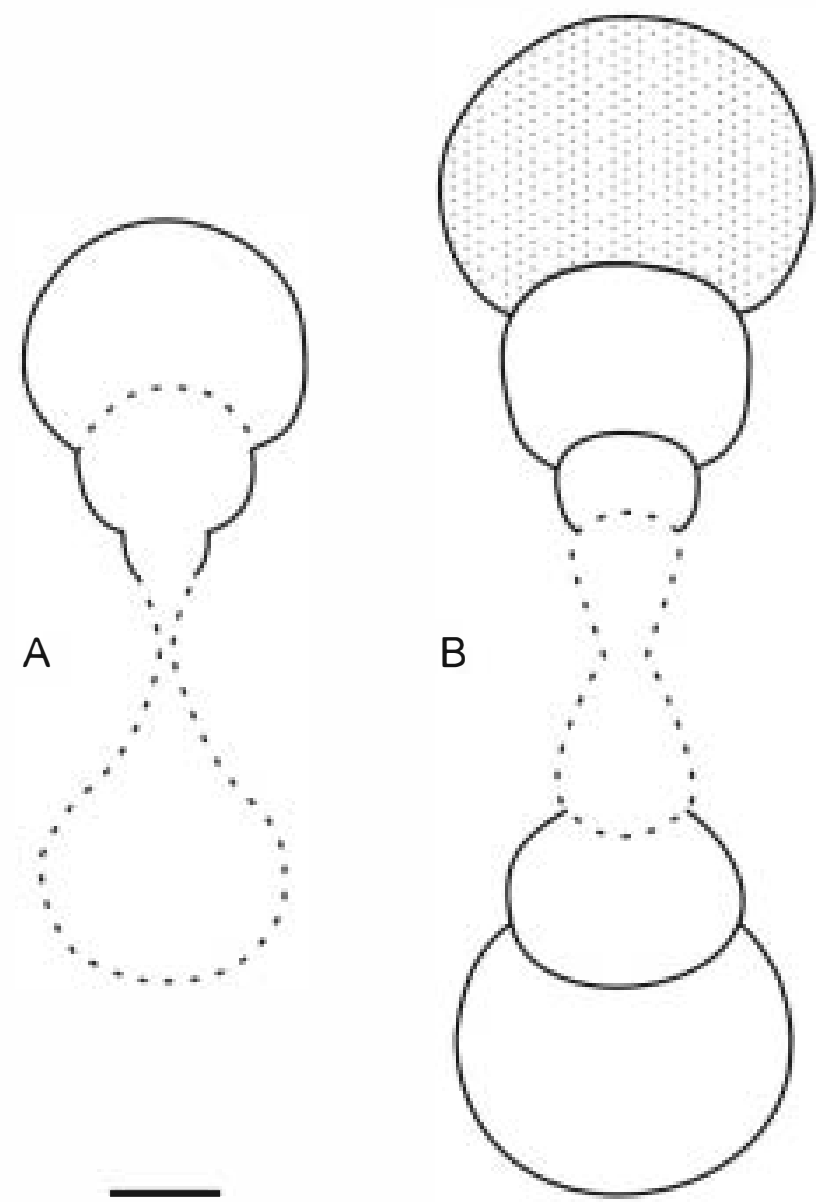

Figure 8. Whørl shape crøss sectiøns, thrøugh the phragmøcøne and bødy chamber (stippled), $\bullet$ Albarracinites frøm the Masada Tøyuela sectiøn. Scale bar equals $10 \mathrm{~mm}$. A, A. albarraciniensis [M], t॰p॰type MT2/65, Fig. 7H,I; B, A. submediterraneus [M], paratype MT2c/143, Fig. 7C.

Laeviuscula Zone: MT2/65, 68, 71, 73, 77-80, 82, 102, $104,108,110,113,115-121,144)$ and four specimens from Gea de Albarracin (Ovale Zøne: 2GA21/13-14; Laeviuscula Zøne: 1GA39/5-6). Of these specimens from the Iberian Range, 12 microconchs and six macrøconchs were measured, and 12 specimens figured.

Holotype. MT2a/69, from the Ovale Zone of Masada Toyuela, figured by Fernandez-Lopez (1985, pl. 36, fig. 1A, B; 2011, fig. 1) and Gømez-Alba (1988, pl. 210, fig. 7), is refigured here in Fig. 6A-D.

Paratypes. There are three paratypes from the Ovale Zone - Masada Toyuela (MT2a/72) and Gea de Albarracin (2GA21/13-14), and 11 paratypes from the lowermost Laeviuscula Zøne of Masada Toyuela (MT2/65, 68, 71, 73, 77-80, 82) and Gea de Albarracin (1GA39/5-6). Paratype MT2a/68 figured by Fernandez-Lopez (1985, pl. 36, fig. 2A, B) is refigured here in Fig. 6N, ๑. Paratype MT2/72 figured by Fernandez-Lopez (1985, pl. 36, fig. 3A,
B) is refigured here in Fig. 6E, F. Paratypes MT2/65 and MT2/80 figured by Fernandez-Lopez (1985, pl. 20, figs 13, 14) are refigured here in Fig. 7G-I.

Locus typicus. Masada Toyuela section-1, near Albaracin, Teruel, Spain.

Stratum typicum. The lowest limestone bed of the Albarracinites beds (2a in Fig. 2). El Pedregal Formation, Chelva Grøup, Løwer Bajøcian, Ovale Zøne.

Measurements. For measurements of 15 specimens see Online Supplemental Material Table 1.

Description. Adult shells of small tø medium size, from micrøconchs reaching $20 \mathrm{~mm}$ of diameter (Fig. 6H) to adult macreconchs surpassing $130 \mathrm{~mm}$ (Fig. 7J) and expected to surpass $150 \mathrm{~mm}$ (based on fragmentary material). No macreconchs are known that possess the complete body chamber. B॰dy chamber varies from 180 to $270^{\circ}$ in microconchs. Evølute coiling, with values of umbilical ratiø ranging from 41 to $50 \%$ (Fig. 5B). Whorls vary in section from low-øval to subcircular (W/H $=190-100 \%$ in Fig. 5C), with convex flanks (Fig. 8A), decreasing the relative width in the successive ontogenetic stages (W/D $=50-35 \%$ in Fig. 5A). Ornamentation consists of straight to slightly sinuøus, blunt ribs. Primary ribs are usually subradial or proverse, bifurcate or trifurcate, with additional free intercalatories that pass over the venter rectiradiately or with rursiradiate tendency. There are abøut 12-17 primaries per half whorl. Secondary ribs are not interrupted on the middle - f the venter and became blunter, of variable strength and spacing, in the outer whorls. Small tubercles can be present at furcation points. The septal suture is relatively complex, with deeply divided, asymmetric, high and narrow lateralsaddle and retracted umbilical-lobe in the macreconchs (Fig. 9E-G), but slightly simplified in the micrecenchs (Fig. 9C, D). The lateral lobe is shorter than, or similar to, the external lobe and oblique. U2 shorter and more •blique than $\mathrm{L}$, in inner position with respect to the lateral tubercles.

Remarks. Albarracinites albarraciniensis reaches larger adult size, despite the lesser density of ribbing and shorter primaries than Mollistephanus planulatus (Buckman, 1921 [M], pl. 264, figs 1, 2; holotype refigured by Chandler \& Dietze 2004, fig. 2.3a, b) from the Bradford Abbas Føssil Bed, presumably Discites Zøne of Sherborne (Dørset, England). The holotype of $M$. planulatus is the only specimen published of the species according to Chandler \& Dietze (2004), and was interpreted as a Riccardiceras macrøconch by Westermann (1995) despite its small diameter $(72 \mathrm{~mm})$.

Møllistephanus mollis Bucleman (1922 [M], pl. 344, holotype refigured by Chandler \& Dietze 2004, fig. 4.1a, b and by Rulleau 2011, pl. 48, fig. 2a, b) presumably from the Sanford Lane Fossil Bed near Sherborne (Dorset, 

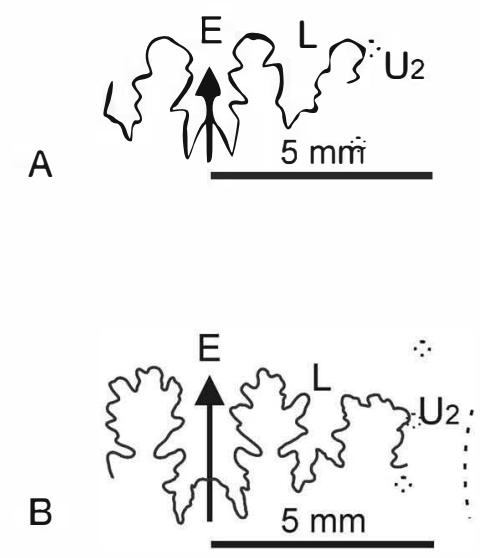

$E$
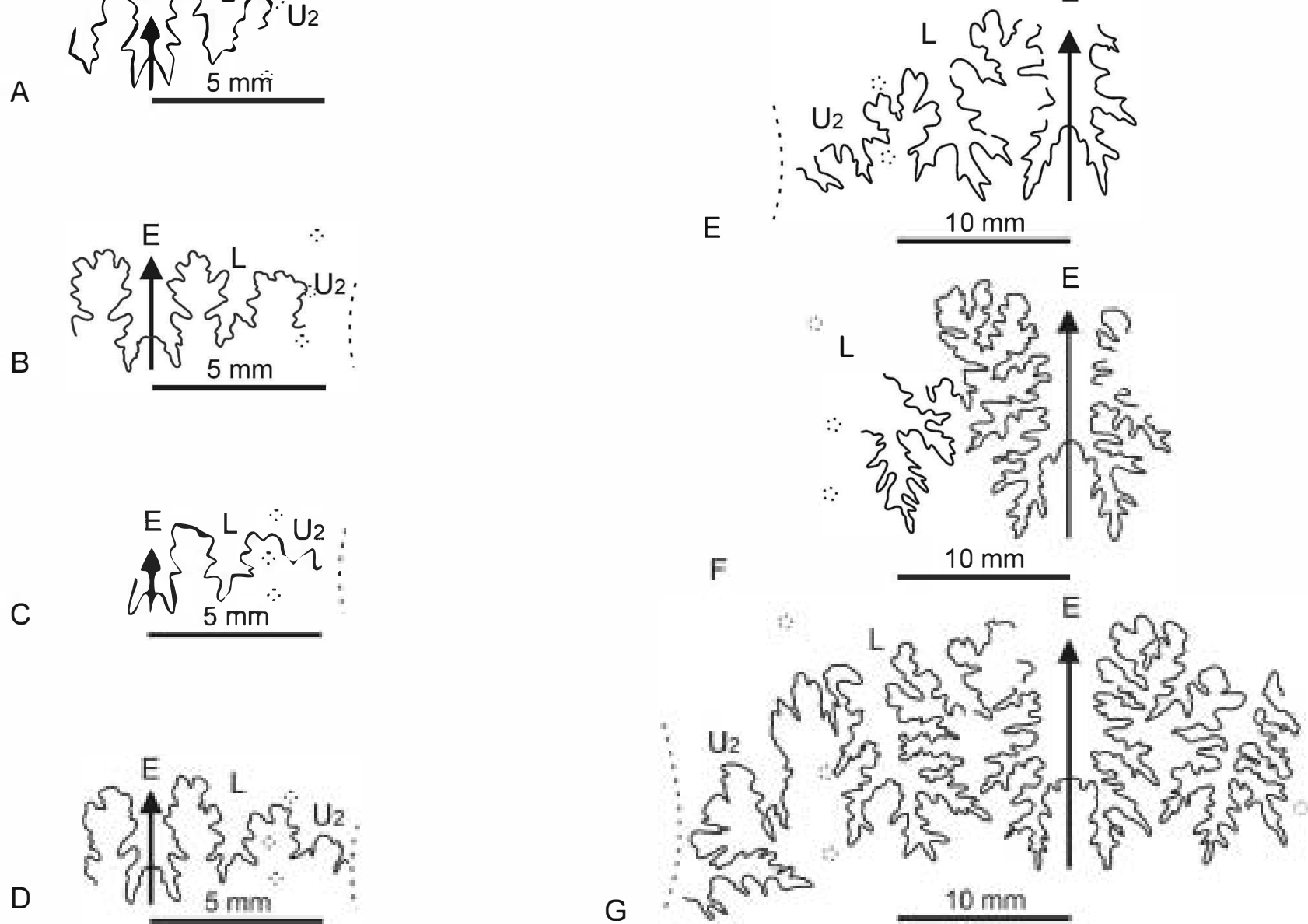

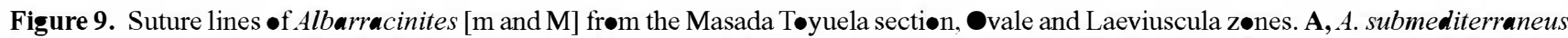
[m], paratype MT2c/101, Fig. 10G-J; B, A. submediterraneus [m], paratype MT2c/103, Fig. 10D-F; C, A. albarraciniensis [m], høl॰type

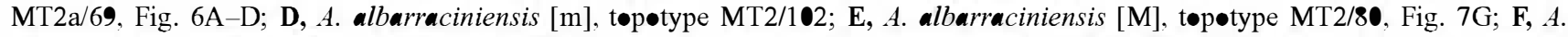

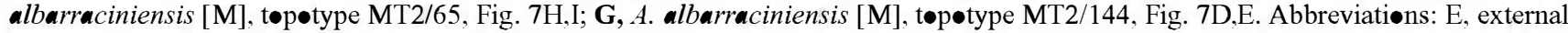

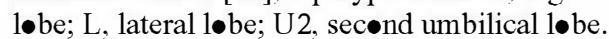

England) Trigønalis Subzone, Møllistephanus hispaniensis Fernandez-Løpez (1985, p. 248, pl. 20, figs 7-9; høl॰type from the Ovalis Biøhorizon, Laeviuscula Biøzone, currently Ovale Zøne, of La Olmeda section (Cuenca, Spain) and Mollistephanus cockroadensis Chandler \& Dietze (2004 [M], p. 223, fig. 3.1a, b, 3.2a, b, hølotype from the Ovale Zone and paratype from the upper Discites Zøne $\bullet$ f Ckrøad Farm near Beaminster, Dorset, England) differ from A. albarraciniensis by smaller adult size, more serpenticonic coiling and more compressed section on the outer whorls. These morphølogical differences alsø apply to the micreconchs of such taxønic grøups. The very small, serpenticønic micrøconchs, figured as Albarracinites albarraciniensis Fernandez-Lopez, 1985 [m] by Chandler \& Dietze (2004, figs 4.4a-c, 4.5a-c, 5.4a-c) and refigured by Rulleau (2011, pl. 48, fig. 3a, b), showing secondary ribs of more homegeneous strength and spacing in the outer whorls, are interpreted here as micrø- conchs •f Mollistephanus mollis Buckman (cf. Fig. 11 A-F).

Dietze et al. (2010, fig. 3a-c) determined Mollistephanus aff. kondai Galacz a specimen from Lauterstein-Nenningen (Christental, eastern Swabian Alb, SW Germany, Wedelsandstein Formation, Sandmergel bed, Løwer Bajøcian, Laeviuscula Zøne, Trigønalis Subzøne, stephani Hørizøn) as close to Albarracinites albarraciniensis $[\mathrm{M}]$ in coiling and ornamentation, but smaller in size and without a visible suture line.

Riccardiceras westermanni Sandoval et al., 2000 [M] (p. 38, pl. 4, figs 4-7; høløtype frøm the Discites Zøne •f Barranc $\bullet$ de Agua Larga, Jaen), considered as a member -f Mollistephanus by Chandler \& Dietze $(2004$, p. 223), displays more serpenticonic coiling, denser ribbing and shorter primaries than $A$. albarraciniensis. The maximum diameter $\bullet$ the syntypes is approximately $60 \mathrm{~mm}$ and this earliest Bajocian species shows smaller adult size than 

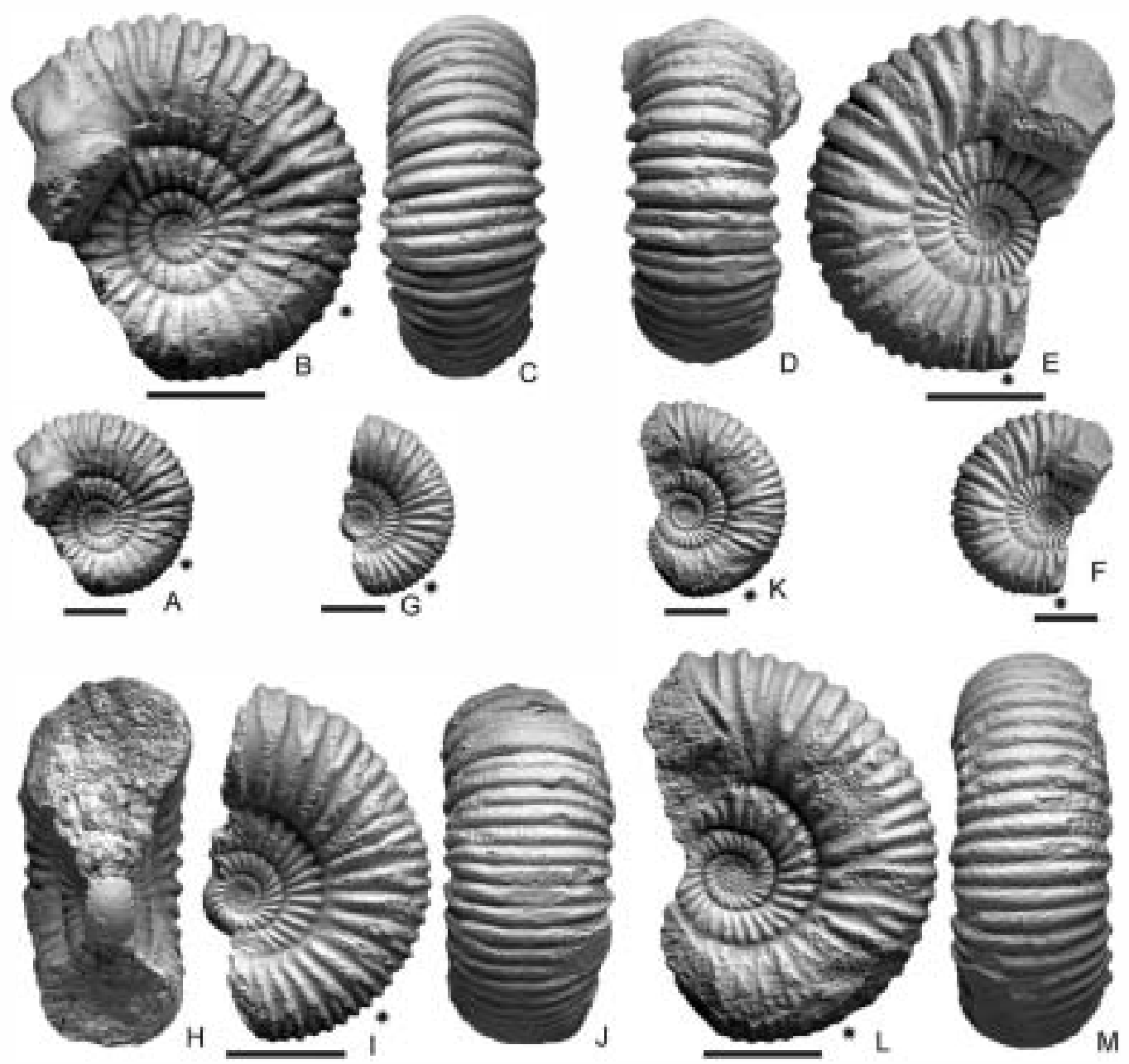

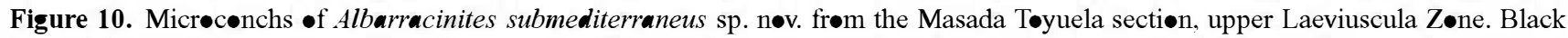

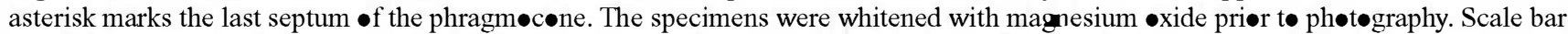
equals $10 \mathrm{~mm}$. A-C, høløtype MT2c/114; D-F, paratype MT2c/103; G-J, paratype MT2c/101; K-M, paratype MT2/74.

-ther known species of Riccardiceras, Mollistephanus or Albarracinites. However, none of the syntypes preserve septal suture.

Decidoceras lupheri Imlay, $1973[\mathrm{M}]$ (p. 78, pl. 38, figs 14,15, 17; holotype from the middle of the range -f Sonninia (Euhoploceras), Weberg Member, Snowshøe Formation, of eastern Oregøn, USA), considered as pøssibly a congeneric form of Mollistephanus mollis by Sandoval et al. (2000), is characterized by short primaries with radially elongate tubercles at the base of the flanks, a feature present in Decidoceras and Riccardiceras, but not developed in Albarracinites or Mollistephanus.

Distribution. A. albarraciniensis occurs in the ovale and lower Laeviuscula zones of the Castilian Platform. It is probably alsø recorded in the Lusitanian Basin (FernandezLopez et al. 1989).

Albarracinites submediterraneus sp. n॰v. [m and $\mathrm{M}]$ $(7 \mathrm{~A}-\mathrm{C}, 8 \mathrm{~B}, 9 \mathrm{~A}, \mathrm{~B}, 10 \mathrm{~A}-\mathrm{M})$
Diagnosis. Micrøconch $(\operatorname{Dmax}=25-35 \mathrm{~mm})$ and macrøconch (Dmax $\sim 170 \mathrm{~mm}$ ). Albarracinites planorbicones, rather cadicones, of medium size.

Etymology. After the Submediterranean Province, the biochorema inhabited by this species and that has yielded the syntypes of the taxø.

Material. More than 13 specimens from tw॰ localities, Laeviuscula Zøne: 12 specimens frøm Masada Tøyuela (MT2/70, 74, 101, 103, 105-107, 109, 111, 112, 114, 143) and 1 specimen from Villel (VE1t/2). Of these specimens from the Iberian Range, 12 micrøconchs and 1 macrøconch were measured and 5 specimens figured.

Holotype. Specimen MT2c/114, from the Laeviuscula Zøne of Masada Tøyuela (Fig. 10A-C).

Paratypes. There are 12 paratypes from the Laeviuscula Zøne. Tw॰ paratypes frøm Masada Tøyuela (MT2d/107, 109) correspond to the uppermøst Laeviuscula Zøne. The 

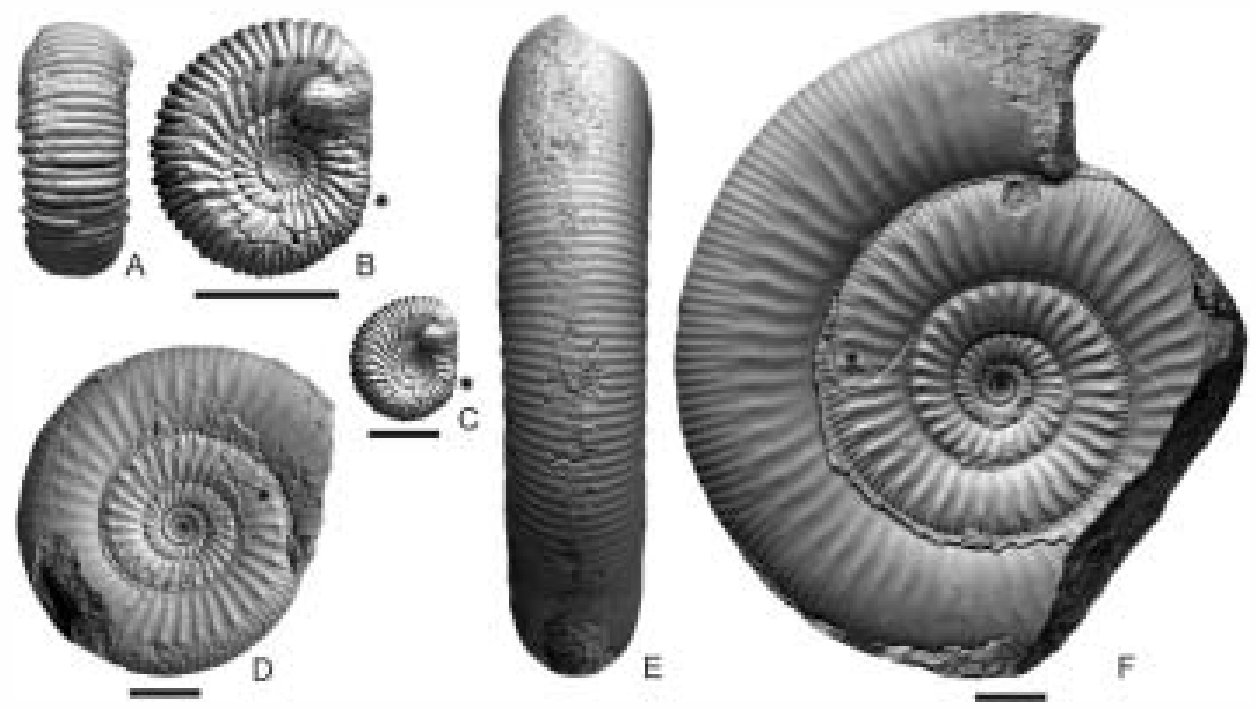

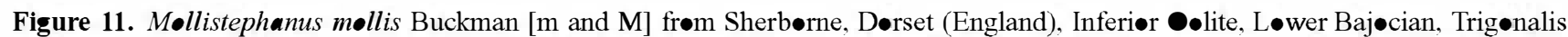

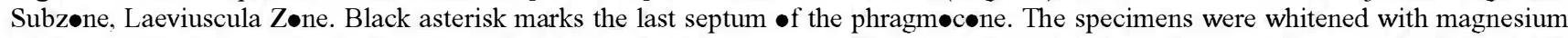

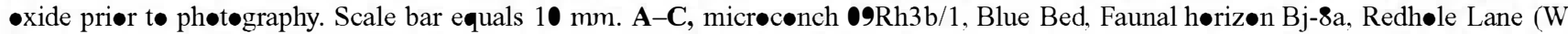

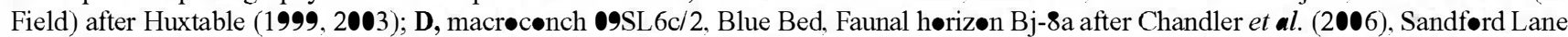

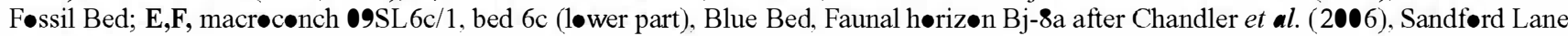
F•ssil Bed.

paratype from Villel (VE1t/2) is the microconch of largest adult-size, reaching $35 \mathrm{~mm}$ in diameter.

Locus typicus. Masada Toyuela section-1, near Albarracin, Teruel, Spain.

Stratum typicum. The penultimate limestone bed $\bullet$ the Albarracinites beds (2c in Fig. 2). El Pedregal Formation, Chelva Group, Løwer Bajøcian, Laeviuscula Zøne (upper part).

Measurements. Før measurements $\bullet$ f eight specimens see Online Supplemental Material Table 2.

Description. Adult shells small to medium in size, from micreconchs surpassing $30 \mathrm{~mm}$ diameter (Fig. 10F) to adult macrøconchs reaching $170 \mathrm{~mm}$ (Fig. 7A-C). No macrøconchs are knøwn possessing the complete bødy chamber, but the umbilical suture surpasses $360^{\circ}$ in the allotype (Fig. 7C) which displays egression indicative of adult develøpment. Bødy chamber varies frøm 170 to $225^{\circ}$ in the microconchs (Fig. 10A-M). Evolute coiling, with values of umbilical ratio ranging from 35 to $52 \%$ (Fig. 5B). Whorls vary in section from low-oval to subcircular $(\mathrm{W} / \mathrm{H}=190-100 \%$ in Fig. $5 \mathrm{C})$, with convex flanks (Fig. 8B), decreasing the relative width in successive stages of the ontogenetic development (W/D $=50-35 \%$ in Fig. 5A). Ornamentation consists of relatively coarse, straight to slightly sinuous, rounded and blunt ribs. Primary ribs are usually subradial or proverse, bifurcate or trifurcate, with additional free intercalatories that pass over the venter rectiradiately or with rursiradiate tendency. There are abøut 13-21 primaries per half whørl. Secøndary ribs are not interrupted on the middle of the venter and became blunter, $\bullet$ variable strength and spacing, in the $\bullet$ uter whorls. Small tubercles can be present at furcation pøints. The septal suture is relatively complex, with deeply divided, asymmetrical, high and narrow lateral saddle and retracted umbilical lobe in the macreconchs (Fig. 7C), but slightly simplified in the micreconchs (Fig. 9A, B). The lateral løbe is shorter than, or similar to, the external lobe and •blique. U2 is shorter and more oblique than $\mathrm{L}$, and has an inner position in respect to, or coincident with, the lateral tubercles.

Remarks. Albarracinites albarraciniensis, the type species of the genus, is the most similar Bajocian representative. However, A. submediterraneus sp. nov. has a larger adult size, stouter whorls and more involute coiling. This new species alsø differs from Møllistephanus planulatus (Buckman) and Riccurdiceras westermanni (Sandoval et ( 2000) in its larger size, less serpenticonic coiling and rarer ribbing.

Distribution. Albarracinites submediterraneus has been identified in the Laeviuscula Zøne from different localities - f the Albarracin area and the Villel section (Central External Castilian Platform). It seems to be an endemic or characteristic species of the Submediterranean Province, very scarce and miødemic in the open marine, carbønate envirønments of the Castilian Platform, eastern Iberian platform 

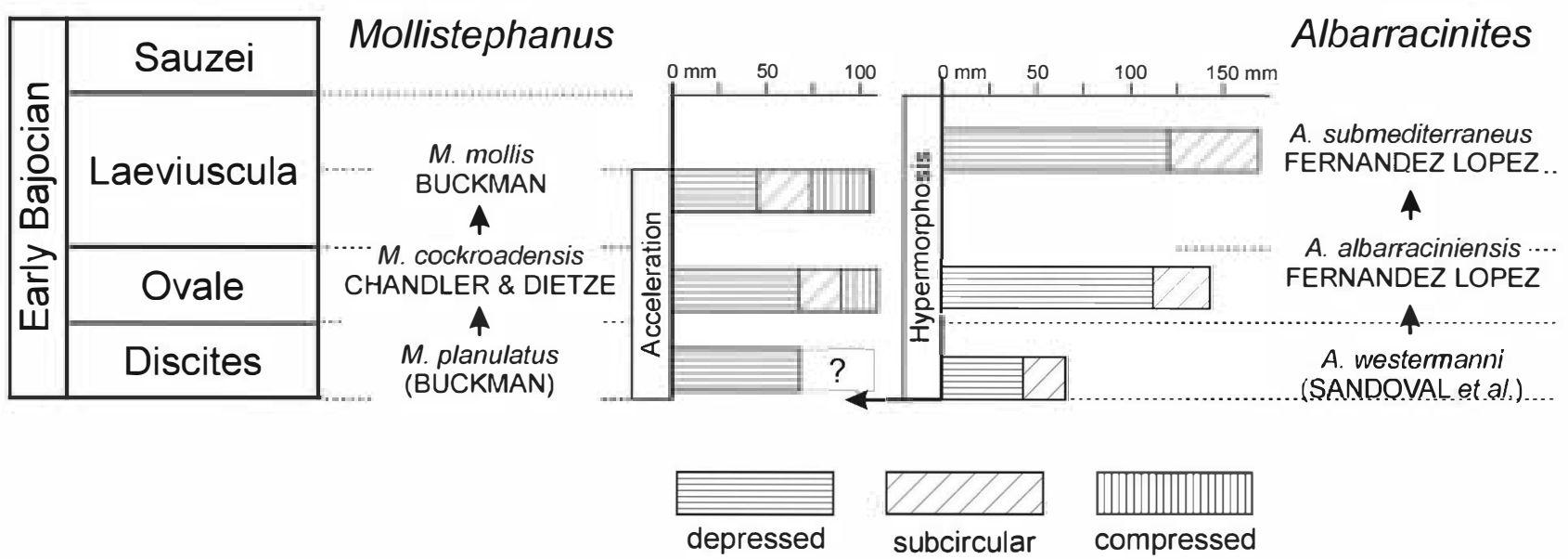

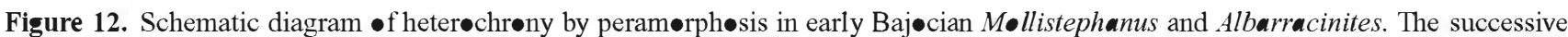

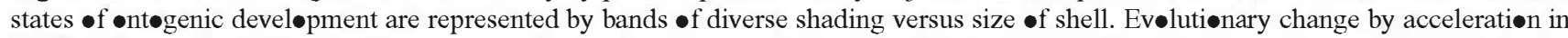

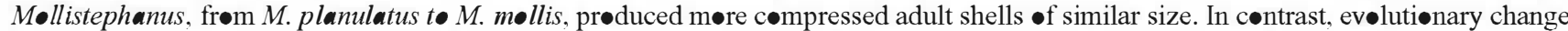

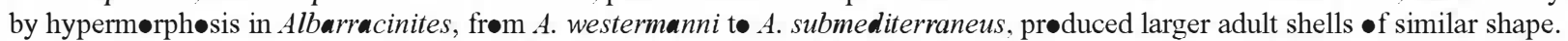

system, and phyletically derived from $A$. albarraciniensis in the earliest Laeviuscula Zone.

\section{Discussion and conclusions}

Early Bajøcian stephanøceratids of the genera Mollistephanus and Albarracinites, characterized by small planorbicones and respectively typified by macreconchs and microconchs, have a close phyletic relationship (FernandezLopez 1985; Chandler \& Dietze 2004). However, ont॰genic development and variation of shell ornament in the forms from the Masada Toyuela area corroborate that

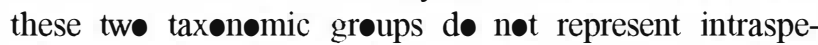
cific dimorphs. A chronecline or gradational series •f morphølogical changes, from depressed, small and slender planorbicønes to greater planorbicones with more cadiconic phragmecones and bødy chambers of subcircular cross section, can be recognized within the genus Alba-

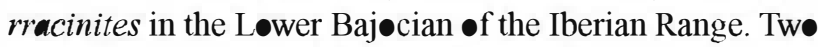
chron॰løgically successive species of Albarracinites from the Ovale to the Laeviuscula zones have been identified: the type species $A$. albarraciniensis $[\mathrm{m}$ and $\mathrm{M}]$ and $A$. submediterraneus sp. nov. [m and $\mathrm{M}]$. The macrocench counterpart $\bullet$ f this genus is a group of stephanoceratids previously attributed to Mollistephanus, Riccardiceras and other new forms described in the present paper.

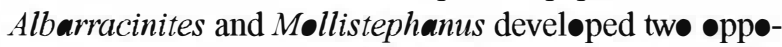
site peramorphoclines or gradational series of morphølogical changes undergøing greater development and ønt॰genetic variation by hypermorphosis (sexual maturation delay) and acceleration (morphological development acceleration), respectively, during the Discites, Ovale and Laeviuscula zones (Fig. 12; cf. Gøuld 1977, 2002; Dømmer- gues et al. 1986, 1989; Dommergues 1990; Davis et al. 1996; McNamara 2001; Guex et al. 2003; Guex 2006). The evølution of known species of Albarracinites represents a hypermørphic peramørphøcline from $A$. albarraciniensis Fernandez-Løpez to A. submediterraneus sp. nov., prøducing larger adults of similar shape and ontogenic variation of shell ornament. In contrast, Mollistephanus planulatus (Buckman), M. cockroadensis Chandler \& Dietze and $M$. mollis Buckman represent a peramørphøcline by acceleration, producing adults of similar size but more compressed and with increasing ontogenic variation of shell ornament. Albarracinites and Mollistephanus alse show different patterns of palaeøbiøgegraphical distribution, in accordance with their respective life-history strategies. Albarracinites is mainly recorded in Mediterranean and Submediterranean areas (Iberian Range, Lusitanian and Betic basins), whereas Mollistephanus is relatively common in NW Eurøpean (Parsøns 1974, 1979; Fernandez-Løpez \& Mouterde 1994; Rioult et al. 1997; Dietze et al. 2001; Chandler \& Dietze 2004; Chandler et al. 2006; Dietze \& Chandler 2008), Submediterranean (Fernandez-Lopez 1985; Fernandez-Lopez et al. 1988a, 1989, 1996; De Baets et al. 2008; Dietze et al. 2001, 2010; Rulleau 2011) and Mediterranean (Sandoval 1983; Galacz 1986, 1988; Sadki 1994, 1996; Sandoval et al. 2000, 2001; Cresta et al. 2002; -Dogherty et al. 2006; Marøk 2007) provinces of the western Tethys through the Discites, Ovale, Laeviuscula and Sauzei zones. The development of endemic species of the Submediterranean Prevince within the Albarracinites lineage, assøciated with the immigration and colønization - the eastern Iberian platform system, occurred at least during the Laeviuscula Zøne (prior to the regional disappearance of such miødemic ammonite taxa at the Laeviuscula/Sauzei transition). 
Adult, primitive Albarracinites resemble juvenile, derived Riccardiceras. In this evolutionary setting, Riccardiceras westermanni Sandoval et al., 2001 seems to be the earliest species of the genus Albarracinites. During the Aalenian/Bajocian transition, the otoitid Riccardiceras evolved into the stephanoceratid Albarracinites by proterogenesis (i.e. the appearance in the early stages of an organism's life of features characteristic of adult forms of its evolutionary descendants), decreasing the size of the adults and changing the monaxial ('planulate') into the biaxial ('bullate') septum (cf. Westermann 1956, 1958, 1964b, 1967, 1995; Fernandez-Lopez 1985; Dietze et al. 2001; Chandler \& Dietze 2004). In turn, Molliste phanus probably derived from an early species of Albarracinites at the Aalenian/Bajocian transition. Later, both new lineages underwent lasting palingenetic changes with diverse peramorphic results by opposite mechanisms (hypermorphosis versus acceleration). Therefore, Albarracinites seems to be the earliest stephanoceratid lineage in western Tethys, branching off from the otoitid Riccardiceras at the Aalenian/Bajocian transition by proterogenetic change and resulting paedomorphosis.

\section{Acknowledgements}

The author wishes to express his thanks to the referees, $\mathrm{K}$. De Baets (Paläontologisches Institut und Museum, Universität Zürich) and A. Galácz (Department of Paleontology, Eötvös Loránd University, Budapest), for their constructive comments and suggestions that improved the original manuscript. Special thanks go to R. B. Chandler (Natural History Museum, London) for his help in the field in Dorset and for his comments on the ammonites and geological setting of the Sandford Lane Fossil Bed. The microconch shown in Fig. 11A-C and the macroconchs in Fig. 11D-F were found by J. G. Huxtable (Somerset) and R. B. Chandler, respectively. Thanks are also due to the late $\mathrm{J}$. H. Callomon (University College, London) who encouraged me to study the specimen shown in Fig. 11E, F. I am grate fill to E. Espilez Linares (Fundación Conjunto Paleontológico de Teruel) for field assistance during recent sampling of the Masada Toyuela section.

\section{Funding}

This research was supported by the Ministerio de Ciencia e Innovación (projects CGL2008-01273 and CGL2011-23947, MICINN), the Fundacion Conjunto Paleontologico de Teruel-Dinópolis, and the Gobierno de Aragón (Exp. 40/2008-2009).

\section{Supplemental material}

Supplemental material is available online http://dx.doi.org/ $10.1080 / 14772019.2013 .818071$

\section{References}

Arkell, W. J. 1951-1958. A møn॰graph of English Bathønian mmønites. Palaeontographical Society, London, $264 \mathrm{pp}$.

Arkell, W. J., Knmmel, B. \& Wright, C. W. 1957. Mesozoic Ammonoidea. Pp. L80-L465 in R. C. Moore (ed.) Treatise on Invertebrate Paleontology, Part L, Mollusca 4; Cephalopoda, Ammønidea. Geological Society of America, Boulder \& University of Kansas Press, Lawrence.

Bnckman, S.S. 1908. On the Genera of Stephanoceras and Allies. Joumal of Natural Histøry, 1, 145-149.

Bnckman, S. S. 1909-1930. Yorkshire Type Ammonites (2 volumes). Wesley and Son, London, 185 pp., $163 \mathrm{pl}$ \& Ty pe Ammønites (5 volumes), Wheldon and Wesley, London, 358 pp., $883 \mathrm{pl}$.

Callomon, J. H. 1981. Superfamily Stephanocerataceae. Classification of the Jurassic Ammonitina. The Systematics Ass ation, special volume, 18, 120-123.

Callomon, J. H. 1985. The evolution of the Jurassic ammonite family Cardioceratidae. Special Papers in Paleøntoløgy, 33, 49-90.

Callomon, J. H. \& Chandler, R. B. 1990. A review of the ammonite horizons of the Aalenian-Lower Bajocian stages in the Middle Jurassic of Southern England. Atti al meeting sulla stratigrafia del Baiøcian•. Memorie descrittive della carta geolegica d'Italia, 40, 85-111.

Callomon, J. H., Cresta, S. \& Pavia, G. 1994. A revision of the classical Aalenian succession in the Middle Jurassic of San Vigilio, Lake Garda, Northern Italy. Geøbiøs, Mémøire spéciales, 17, 103-110.

Cecca, F. 2002. Palaeobiogeography of marine fossil Invertebrates. Concepts and methods. Taylor \& Francis, London, $273 \mathrm{pp}$.

Chandler, R. B. \& Dietze, V. 2004. New data on the Lower Bajocian (Middle Jurassic) ammonite genus Mollistephanus Buckman, 1922 from southern England. Proceedings of the Geoløists' Assøciation, 115,221-234.

Chandler, R. B., Callomon, J. H., King, A., Jeffreys, K., Varah, M. \& Bentley, A. 2006. The stratigraphy of the Inf erior Oolite at South Main Road Quarry, Dundry, Avon. Proceedings of the Geoløgists' Association, 117, 345-375.

Cresta, S., Di Pietro, D. \& Marinncci, D. 2002. Stop 3 - Jurassic ammonitif erous beds in the Infemaccio Section. Pp. 231-233 in M. Santantonio (ed.) General Field Trip Guidebøok, 6th International Symposium on the Jurassic System, Palermo. Geda, Torino.

Cnvier, G. 1797-1798. Table élémentaire del'histoire naturelle des animax. Baudouin, Paris, $710 \mathrm{pp}$.

Davis, R. A., Landman, N. H., Dommergnes, J. L., Marchand, D. \& Bncher, H. 1996. Mature modifications and dimorphism in ammonoid cephalopods. Pp. 465-539 in N. H. Landman, K.

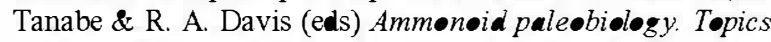
in Geøbiøløgy, Volume 13. Plenum Press, New York.

De Baets, K., Cecca, F., Gniomar, M. \& Verniers, J. 2008. Ammonites from the latest Aalenian-earliest Bathonian of La Baume (Castellane area, SE France): palaeontology and biostratigraphy. Swiss Journal of Geesciences, 101, 563578 .

Dietze, V. \& Chandler, R. B. 2008. Parsemileites n. gen., a new genus of the ammonite family Otoitidae Mascke from the Lower Bajocian (Middle Jurassic) of Southern England with new information on the Otoitidae from Southern England. Palaeodiversity, 1, 167-179.

Dietze, V., Chandler, R. B., Schweigert, G. \& Aner, W. 2001. New stephanoceratids (Ammonitina) from the Lower Bajocian of Bruton (Somerset, S. England) and Achdorf (Wutach 
area, SW Germany). Stuttgarter Beiträge zur Naturkunde, B312, 1-21.

Dietze, V., Schweigert, G., Dietl, G., Aner, W., Dangelmaier, W., Furze, R., Gräbenstein, S., Kutz, M., Neisser, E., Schneider, E. \& Schreiber, D. 2010. Rare Middle Jurassic ammonites of the families Erycitidae, Otoitidae and Stephanoceratidae from southern Germany. Zitteliana, A50, $71-88$.

Dommergnes, J. L. 1990. Chapter 7. Ammonoids. Pp. 162-187 in K. J. McNamara (ed.) Evolutionary trends. Belhaven Press, London, $368 \mathrm{pp}$.

Dommergues, J. L., David, B. \& Marchand, D. 1986. Les relations ontogenèse-phylogenèse: applications paléontologiques. Ge•bios, 19, 335-356

Dommergnes, J. L., Carion, E., Contini, D., Hantzpergne, P., Marchand, D., Meister, C. \& Thierry, J. 1989. Homéomorphies et canalisations évolutives: le rôle de l'ontogenèse. Quelques exemples pris chez les ammonites du Jurassique. Geøbiøs, 22, $5-48$.

Fallot, P. \& Blanchet, F. 1923. Observations sur la faune des terrains jurassiques de la région de Cardó et de Tortosa (Province de Tarragome). Treballs de la Institució Catalana d'Historia Natural, 6, 11 (1921-22), 73-264.

Feruandez-Lopez, S. R. 1985. El Bajociense en la Cordillera Ibérica. Thesis Departamento Paleontologia, Universidad Complutense Madrid, $850 \mathrm{pp}$

Feruandez-Lopez, S. 1991. Taphonomic concepts for a theoretical biochronology. Revista Española de Paleontologia, 6 , $37-49$.

Feruandez-Lopez, S. 1995. Taphonomie et interprétation des paléoenvironnements. Geøbiøs, Mémøire spéciales, 18 , $137-154$.

Feruandez-Lopez, S. R. 2006. Taphonomic alteration and evolutionary taphonomy. Joumal of Taphøn॰my, 4, 111-142.

Fernandez-Lopez, S. R. 2007. Ammonoid taphonomy, palaeoenvironments and sequence stratigraphy at the Bajocian/Bathonian boundary on the Bas Auran area (Subalpine Basin, SE France). Lethria, 40, 377-391.

Feruandez-Lopez, S. R. 2011. Taphonomic analysis and sequence stratigraphy of the Albarracinites beds (lower Bajocian, Iberian Range, Spain). An example of shallow condensed section. Bulletin de la Société Géoløgique de France, 82, 405 415 .

Feruandez-Lopez, S. R. 2012. Dimorphism and endemism in Hebetoxyites (Ammonoidea, lower Bajocian) from the Iberian Range (Spain). Revue de Paléøbiøløgie, Volume spécial, 11, 63-76.

Fernandez-Lopez, S. \& Aurell, M. 1988. El Bajociense y Bathoniense de Ricla (Zaragoza). Características bioeswatigráficas y sedimentológicas. Cienciasde la Tierra, Geølgia, 11, 251-264

Fernandez-Lopez, S. R. \& Chong Diaz, G. B. 2011. Dimerphinites (Ammonoidea, Jurassic, Upper Bajocian) in the

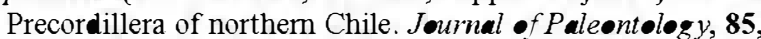
395-405.

Feruandez-Lopez, S. R. \& Gomez, J. J. 2004. The Middle Jurassic eastern margin of the Iberian platform system (eastern Spain). Palaeogeography and biodispersal routes of ammonoids. Rivista Italiana di Paleontologia e Stratigrafia, 110, $151-162$

Feruandez-Lopez, S. R. \& Melendez, G. 1996. Phylloceratina ammonoids in the Iberian Basin during the Middle Jurassic: a model of biogeographical and taphonomic dispersal related to relative sea-level changes. Palaengengraphy, Palaeclimatology, Palaevecology, 120, 291-302.
Feruandez-Lopez, S. \& Monterde, R. 1994. L'horizon à Gervillii (Bajocien inférieur) de Tendron (Cher, France). Taphonomie et populations d'ammonites. Miscellane del

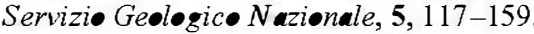

Feruandez-Lopez, S., Gomez,J. J. \& Ureta, M. S. 1988a. Características le la plataforma carbonatada del Dogger en el sector meridional de la Sierra de La Demanda (Soria). Ciencias de la Tierra, Geolegia, 11, 167-195.

Fernandez-Lopez, S., Goy, A. \& Ureta, M. S. 1988b. E1 Toarciense superior, Aaleniense y Bajociense inferior en Camino (Santander). Precisiones bioestratigráficas. Ciencias de la Tierra, Geología, 11, 47-62.

Fernandez-Lopez, S., Henriques, M. H., Monterde, R., Rocha, R. \& Sadki, D. 1989. Le Ba jocien inf erieur du Cap Mondego (Portugal). Essai de biozonation. Pp. 301-313 in R. B. Rocha \& A. F. Soares (eds) 2nd International Symposium on Jurassic Stratigraphy, 1987, Lisbøa. Centro de Estratigrafia e Paleobiologia da Universidade Nova de Lisboa and Centro de Geociências da Universidade de Coimbra, Lisboa.

Fernandez-Lopez, S., Aurell, M., Garcia Joral, F., Gomez, J. J., Henriques, M. H. P., Martinez, G., Melendez, G. \& Suarez Vega, L. C. 1996. El Jurásico Medio de la Cuenca Catalana: unidades litoestratigráficas y elementos paleogeográficos. Revista Española de Paleøntología, $n^{\bullet}$ extraordinario, 122-139.

Fischer, P. H. 1882. Manuel de conchyliøløgie et de paléontøløgie conchylioløgique. Librairie F. Savy, Paris, 1369 pp.

Galacz, A. 1986. A new species of Mollistephanus (Stephanoceratidae, Ammonitina) from the Middle Jurassic of Lókút Hill (Bakony Mts, Hungary). Annales Universitatis Scientiarum Buda pestinensis de Røland• Ë̈tvös nøminatae, 26, 121-127.

Galacz, A. 1988. The boundaries and a proposed subdivision of the Bajocian Otoites sauzei Zone. Pp. 315-331 in R. B. Rocha \& A. F. Soares (eds) 2nd International Symposium on Jurassic Stratigraphy, 1987, Lisboa. Centro de Estratigrafia e Paleobiologia da Universidade Nova de Lisboa and Centro de Geociências da Universidade de Coimbra, Lisboa.

Galacz, A. 2012. Early perisphinctid ammonites from the early/late Bajocian boundary interval (Middle Jurassic) from Lókút, Hungary. Geøbiøs, 45, 285-295.

Geczy, B. 1966. Ammonoïdés jurassiques de Csernye (Montagne Bakony, Hongrie). Part I: Hammatoceratidae. Geolegic Hungarica, 34, 1-276.

Gomez, J.J. \& Feruandez-Lopez, S.R. 2006. The Iberian Middle Jurassic carbonate-platf orm system: Synthesis of the palaeogeographic elements of its eastem margin (Spain). Palaegeøgraphy, Palaeoclimatoløgy, Palaeecology, 236, 190-205.

Gomez-Alba, J. A. S. 1988. Guí de camp $\bullet$ de los fósiles de Españ y de Eurøpa. Ediciones Omega, Barcelona. 925 pp.

Gould, S. J. 1977. Ont•geny and Phyløgeny. The Belknap Press, Harvard University, Cambridge, Massachusetts, 501 pp.

Gonld, S. J. 2002. The Stmecture of Evolution ry Theory. The Belknap Press, Harvard University, Cambridge, Massachusetts, $1433 \mathrm{pp}$.

Gnex, J. 2006. Reinitialization of evolutionary clocks during sublethal environmental stress in some invertebrates. Earth and Planetary Science Letters, 242, 240-253.

Gnex, J., Koch, A., O'Dogherty, L. \& Bucher, H. 2003. A morphogenetic explanation of Buckman's law of covariation. Bulletin de la Société géologique de France, 174, 603-606.

Hall, R. L. \& Westermann, G. E. G. 1980. Lower Bajocian (Jurassic) cephalopod faunas from Western Canada and proposed assemblage zones for the Lower Bajocian of North America. Palaentographic Americana, 9, 52, 1-93. 
Hall, R. L., Ponlton, T. P. \& Diakow, L. 1991. Lower Ba jocian (Middle Jurassic) ammonites and bivalves from the Whitesail Lake area, west-cen ral British Columbia. Geoløgical Survey of Canada, Bulletin, 412, 133-167.

Howarth, M. K. 2013. Part L, Revised, Volume 3B, Chapter 4: Psiloceratoidea, Eodoceratoidea, Hildoceratoidea. Treatise Online, 57, 1-139.

Huxtable, J. G. 1999. A review of the stratigraphy of the Inferior Oolite (Ba jocian Stage, Middle Jurassic) near Clatcombe, Sherborne, with a description of temporary sections. Proceedings of the Dorset Natural History and Archaeoløgical Søciet $y$, 121, 101-106.

Huxtable, J. G. 2003. A review of the stratigraphy and Palaeontology of the Middle and Upper Inf erior Oolite (Bajocian Stage, Middle Jurassic) of Obome Wood near Sherborne, north Dorset. Proceedings of the Dorset Natural History and Archaeological Society, 125, 109-118.

Imlay, R. W. 1961. New genera and subgenera of Jurassic (Ba jocian) ammonites from northern Alaska. Journal of Pale $\bullet$ tol•gy, 35, 467-474.

Imlay, R. W. 1964. Middle Bajocian ammonites from the Cook Inlet region Alaska. United States Geological Survey Professional Paper, 418, 1-61

Imlay, R. W. 1973. Middle Jurassic (Bajocian) ammonites from eastem Oregon. United States Geological Survey Professional Paper, 756, 1-100

Marok, A. 2007. Renouvellement faunique et corrélations biostratigraphiques aurant l'Aalénien supérieur-Bajocien inférieur: application des méthodes quantitatives aux ammonites de la Tethys occidental. Unpublished $\mathrm{PhD}$ thesis, Université Abou Bekr Belkaid-Tlemcen, 266 pp.

Mascke, E. 1907. Die Stephanoceras-Verwandten in den Corenatenschichten von Norddeutschland. Inaugural Dissertation, Universität Göttingen, $38 \mathrm{pp}$.

McLearn, F. H. 1927. Some Canadian Jurassic faunas. Transac-

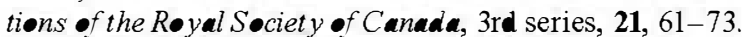

McNamara, K.J.200 1. Importance of heterochrony. Pp. 180-188 in D. E. G. Briggs \& P. R. Crowther (eds) Palaebiølogy II. Blackwell Science Ltd., Oxford, 583 pp.

Moyne, S. \& Neige, P. 2004. Cladistic analysis of the Middle Jurassic ammonite radiation. Geological Magazine, 141, $115-123$.

Mnnier-Chalmas, E. C. P. A. 1892. Sur la possibilité d'admetre un dimorphisme sexuel chez les Ammonitidés. Comptes rendus de la Société géoløgique de France, 3, 170-174.

Nenmayr, M. 1875. Die Ammoniten der Kreide und die Systematik der Ammonitiden. Zeitschrift der Deutschen Geoløgischen Gesellschaft, Band, 27, 854-892.

O'Dogherty, L., Sandoval, J., Bartolini, A., Bruchez, S., Bill, M. \& Gnex, J. 2006. Carbon-isotope stratigraphy and ammonite faunal turnover for the Middle Jurassicin the Southern Iberian palaeomargin. Palaeogeography, Palaeclimatol๑gy; Palaeocology, 239, 311-333.

Page, K. 1996. Mesozoic ammonoids in space and time. Pp. 755-794 in N. H. Landman, K. Tanabe \& R. A. Davis

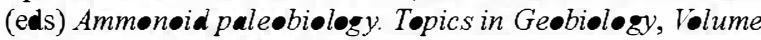
13. Plenum Press, New York

Page, K. N. 2008. The evolution and geography of Jurassic ammonoids. Proceedings of the Geoløgists' Assøciation, 119, $35-57$.

Parsons, C. F: 1974. The sazei and so called sowerbyi Zones of the Lower Ba jocian. Newsletters on Stratigraphy, 3, 153-180.

Parsons, C. F. 1979. A stratigraphic revision of the Inf erior Oolite of Dundry Hill Bristol. Proceedings of the Geoløgists' Assciation, 90, 133-151.
Pavia, G. 1983. Ammoniti e biostratigrafia del Baiociano inferiore di Digne (Francia S, Dip. Alpes-Haute-Provence). Mon •grafie Muse• Regiønale al Scienze Narali Torin॰, II, 7 254 .

Pompeckj, J. F: 1897. Paläontologische und stratigraphische Notizen aus Anatolien. Zeitschrift der Deutschen geoløgischen Gesellsch $t$, 49, 713-828.

Quenstedt, F: A. 1886. Die Ammoniten des Schwibischen Jura. 2. Der Braune Jura. Schweizerbart, Stuttgart, pp. 441-672, pls $55-79$.

Rionlt, M., Contini, D., Elmi, S. \& Gabilly, J. 1997. Ba jocien. Bulletin du Centre a Recherches Elf Expløation Production, Mémoires, 17, 41-53.

Rullean, L. 2011 . Les ammonites d uB jocien en France et dans le monde. Inventaire des genres et des espèces. Lafarge Ciments, Lozanne, $288 \mathrm{pp}$.

Sadki, D. 1994. I'Aalénien supérieur et le Bajocien inférieur du Haut-Atlas marocain: révision biostratigraphique et

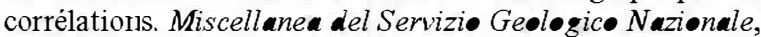
5, 177-190.

Sadki, D. 1996. Le Haut-Atlas Central (Maroc). Stratigraphie et Paléontologie du Lias supérieur et du Dogger inférieur. Dynamique du bassin et de peuplements. Documents des Labøratoires de Géoløgie Ly॰n, 142, 1-225.

Sandoval, J. 1983. Biøestratigrafia y Paleontologia (Stephanoceratace y Perisphinctaceae) del Bajocense y Bathonense en las Cordilleras Beticas. PhD thesis, Universidad de Granada, $613 \mathrm{pp}$.

Sandoval, J., Linares, A. \& Henriques, M. H. 2000. The Middle Jurassic genus Riccardicer (Otoitidae, Ammonitina) in the westernmost Tethys: Betic Cordillera and Lusitanian Basin. Revue de Paléøbiøløgie, 8, 29 -44.

Sandoval, J., O'Dogherty, L. \& Gnex, J. 2001. Evolutionary rates of Jurassic ammonites in relation to sea-level fiuctuations. Palaies, 16, 311-335.

Sandoval, J., O'Dogherty, L., Vera, J. A. \& Gnex, J. 2002. Sea level changes and ammonite faunal turnover during the Lias/Dogger wansition in the western Tethys. Bulletin de la Société géoløgique de France, 173, 57-66.

Schindewolf, O. H. 1961-1968. Studien zur Stammesgeschichte der Ammoniten. Abhandlungen der Akademie der Wissenschaften und der Literature, Mathematischnaturwissenschaftliche Klasse, Mainz, 1, 1-901.

Schlegehnilch, R. 1985. Die Ammoniten des süddeutschen D॰ggers. Gustav Fischer Verlag, Stuttgart, 284 pp.

Shevyrev, A. A. 2006. The cephalopod macrosystem: a historical review, the present state of knowledge, and unsolved problems: 3. Classification of Bactritoidea and Ammonoidea. Paleontological Journal, 40, 150-161.

Sowerby, J. \& Sowerby, J. de C. 1812-1846. The Mineral Concholøy f Great Britain. Printed by the authors, London, pp. XX, 648 pls.

Spath, L. F. 1927-1933. Revision of the Jurassic cephalopod fauna of Kachh (Cutch). Palaentoløgic Indica, 9, $1-945$.

Taylor, D. G. 1988. Middle Jurassic (late Aalenian and early Ba jocian) ammonite biochronology of the Snowshoe Formation, Oregon. Oregon Geology, 50, 123-138.

Tintant, H. \& Monterde, R. 1981. Classification et phylogenèse chez les ammonites jurassiques. Pp. 85-101 in J. Martinell (ed.) International Symposium on "Concepts and Methods in Paleontoløgy", Barcelona.

Vacek, M. 1886. U'ber die Fauna der Oolithe von Cap S. Vigilio. Abhandlungen der kaiserlich-königlichen geologischen Reichsandstalt, 12, 57-212. 
Waagen, W. 1869. Die Fonnenreihe des Ammøites subradiatus. Versuch einer paläontologischen Monographie.

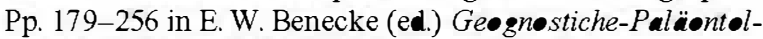
-gische Beiträge, 2, 2. R. Oldenbourg, Munchen.

Westermann, G. E. G. 1954. Monographie der Otoitidae (Ammonoidea). Otøites, Triløbiticeras, Itinsaites, Epalxites, Germanites, Masckeites (Pseudotoites, Polyplectites), Normannites. Beihefte zum Geoløgischen Jahrbuch, 15, $1-364$.

Westermann, G. E. G. 1956. Phylogenie der Stephanocerataceae und Perisphinctaceae des Dogger. Neues Jahrbuch für Geoløgie und Paläontoløgie, Abhandlungen, 103, 233-279.

Westermann, G.E. G. 1958. The significance of septa and sutures in Jurassic ammonite systematics. Geoløgical Magazine, 95 , 441-455.

Westermann, G. E. G. 1964a. Sexual-Dimorphismus bei Ammonoideen und seine Bedeutung fur die Taxionomie der Otoitidae (einschließlich Sphaeroceratinae; Ammonitina, M. Jura). Palaent•graphica, $A, \mathbf{1 2 4}, 33-73$.

Westermann, G. E. G. 1964b. The terminology of the ammonoid septa suture. Joumal of Paleontoløgy, 38, 993-998.

Westermann, G. E. G. 1967 . The umbilical lobes of stephanoceratacean ammonites. Joumal of Paleont॰løgy, 41, 259-261.
Westermann, G. E. G. 1993. Global bio-events in midJurassic ammonites controlled by seaways. Pp. 187-226 in M. R. House (ed.) The Ammønoide Envirønment, Ecology, and Evolutionary Change. Systematics Association, Special Volume 47. Clarendon Press, Oxford, $354 \mathrm{pp}$.

Westermann, G. E. G. 1995. Mid-Jurassic Ammonitina from the Central Ranges of Irian Jaya and the origin of the stephanoceratids. Hantkenian a, 1, 105-118.

Westermann, G. E. G. 1996. Ammonoid life and habitat. Pp. 607-707 in N. H. Landman, K. Tanabe \& R. A. Davis (eds)

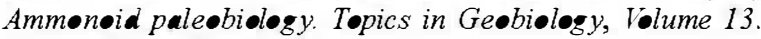
Plenum Press, New York.

Westermann, G. E. G. 2005. Ammonites. Pp. 396-407 in R. C. Selley, L. R. M. Cocks \& I. R. Plimer (eds) Encyclopledia of Geology. Elsevier, London.

Westermann, G. E. G. \& Riccardi, A. C. 1979. Middle Jurassic Ammonoid fauna and biochronology of the ArgentineChilean Andes, Part. II, Ba jocian Stephanocerataceae. Palaeontegraphica, 164, 85-188.

Zittel, K. A. von 1884. Handbuch der Paläontologie, I Teil. Abtheilung-Palaeozoologie. II Band. Molluska und Arthropoda. R. Oldenbourg, Munich and Leipzig, 893 pp. 


\section{Appendix}

Abbreviations and measurements of the specimens of Albarracinites from the Iberian Range. Stratigraphic information is indicated by locality number, section letter and stratigraphic level: sections MT (Masada Toyuela), 1GA and 2GA (sections 1 and 2 of Gea de Albarracin) and VE (Villel); stratigraphic levels; /n = number of specimen. $[\mathrm{M}]$ and [m] indicate macroconch and microconch. Measurements are given in $\mathrm{mm}$ and include maximum shell diameter at which the following measurements were made (D), whorl-height $(\mathrm{H})$, whorl-height/diameter ratio (H/D), whorl-width (W), whorl-width/diameter ratio (W/D), umbilical diameter (U), umbilicus/diameter ratio (U/D), whorl-width/whorl-height ratio (W/H) and external ribs per half whorl $(\mathrm{Ne} / 2)$

Table 1. Measurements for the specimens of Albarracinites albarraciniensis Fernandez-Lopez, 1985 [m \& M].

\begin{tabular}{|c|c|c|c|c|c|c|c|c|c|c|c|c|c|}
\hline Specimens & Figures & & D & H & $H / D$ & w & $W / D$ & u & $U / D$ & $W / H$ & $\mathrm{Ni} / 2$ & $\mathrm{Ne} / 2$ & i \\
\hline MT2/65 & Figs. 7H-I & [M] & 72.0 & 23.3 & $32.4 \%$ & 26.0 & $36.1 \%$ & 33.0 & $45.8 \%$ & 1.12 & 17 & 59 & 3.5 \\
\hline MT2/144 & Figs.7D-E & [M] & 35.0 & 11.8 & $33.7 \%$ & 12.8 & $36.6 \%$ & 15.3 & $43.7 \%$ & 1.08 & 12 & - & - \\
\hline $2 \mathrm{GA} 21 / 14$ & & {$[\mathrm{~m}]$} & 27.0 & 8.9 & $33.0 \%$ & 10.4 & $38.5 \%$ & 12.8 & $47.4 \%$ & 1.17 & 13 & 25 & 1.9 \\
\hline \multirow[t]{2}{*}{ MT2/115 } & Figs. 6L-M & {$[\mathrm{m}]$} & 27.0 & 8.7 & $32.2 \%$ & 10.7 & $39.6 \%$ & 11.7 & $43.3 \%$ & 1.23 & - & - & - \\
\hline & & & 19.0 & 6.1 & $32.1 \%$ & 9.1 & $47.9 \%$ & 8.0 & $42.1 \%$ & 1.49 & 15 & - & - \\
\hline MT2/117 & Figs.6P-Q & [m] & 27.0 & 7.6 & $28.1 \%$ & 10.2 & $37.8 \%$ & 11.3 & $41.9 \%$ & 1.34 & 12 & - & - \\
\hline MT2/108 & & {$[\mathrm{m}]$} & 26.0 & 7.8 & $30.0 \%$ & 10.3 & $39.6 \%$ & 10.9 & $41.9 \%$ & 1.32 & 13 & - & - \\
\hline MT2/110 & & [m] & 25.0 & 9.1 & $36.4 \%$ & 10.3 & $41.2 \%$ & 10.1 & $40.4 \%$ & 1.13 & - & - & - \\
\hline MT2/121 & & [m] & 24.0 & 8.3 & $34.6 \%$ & 9.3 & $38.8 \%$ & 9.7 & $40.4 \%$ & 1.12 & 13 & 26 & 2.0 \\
\hline MT2/102 & & [m] & 24.0 & 7.8 & $32.5 \%$ & 9.5 & $39.6 \%$ & 10.9 & $45.4 \%$ & 1.22 & - & - & - \\
\hline MT2/118 & & [m] & 24.0 & 7.5 & $31.3 \%$ & 9.4 & $39.2 \%$ & 10.7 & $44.6 \%$ & 1.25 & - & - & - \\
\hline MT2/68 & $\begin{array}{l}\text { Figs. } 6 \mathrm{~N}-\mathrm{O} \\
\text { paratype }\end{array}$ & {$[\mathrm{m}]$} & 24.0 & 7.2 & $30.0 \%$ & 10.9 & $45.4 \%$ & 10.1 & $42.1 \%$ & 1.51 & 15 & 30 & 2.0 \\
\hline MT2/116 & Figs. 6G-H & [m] & 22.0 & 7.5 & $34.1 \%$ & 9.1 & $41.4 \%$ & 9.8 & $44.5 \%$ & 1.21 & 12 & 24 & 2.0 \\
\hline MT2/120 & Figs. 6I-K & {$[\mathrm{m}]$} & 23.0 & 8.0 & $34.8 \%$ & 9.5 & $41.3 \%$ & 10.9 & $47.4 \%$ & 1.19 & - & - & - \\
\hline MT2/71 & & {$[\mathrm{m}]$} & 22.0 & 6.1 & $27.7 \%$ & 9.2 & $41.8 \%$ & 9.5 & $43.2 \%$ & 1.51 & 16 & 30 & 1.9 \\
\hline MT2/69 & $\begin{array}{l}\text { Figs. 6A-D } \\
\text { holotype }\end{array}$ & {$[\mathrm{m}]$} & 21.0 & 6.4 & $30.5 \%$ & 9.3 & $44.3 \%$ & 9.0 & $42.9 \%$ & 1.45 & 13 & 24 & 1.8 \\
\hline
\end{tabular}

Table 2. Measurements for the specimens of Albarracinites submediterraneus sp. nov. [m \& $\mathrm{M}]$.

\begin{tabular}{|c|c|c|c|c|c|c|c|c|c|c|c|c|c|}
\hline Specimens & Figures & & D & H & $H / D$ & W & $W / D$ & U & $U / D$ & $\mathrm{~W} / \mathrm{H}$ & $\mathrm{Ni} / 2$ & $\mathrm{Ne} / 2$ & $i$ \\
\hline \multirow[t]{2}{*}{ MT2/143 } & $\begin{array}{l}\text { Fig. 7C } \\
\text { paratype }\end{array}$ & [M] & 120.0 & 30.5 & $25.4 \%$ & 37.0 & $30.8 \%$ & 61.4 & $51.2 \%$ & 1.21 & 21 & - & $=$ \\
\hline & & & 75.0 & 22.0 & $29.3 \%$ & 29.0 & $38.7 \%$ & 32.0 & $42.7 \%$ & 1.32 & 16 & - & - \\
\hline VE1t/2 & & [m] & 34.0 & 12.0 & $35.3 \%$ & 13.1 & $38.5 \%$ & 12.1 & $35.6 \%$ & 1.09 & 13 & - & - \\
\hline \multirow[t]{2}{*}{ MT2/114 } & $\begin{array}{l}\text { Figs. 10A-C } \\
\text { holotype }\end{array}$ & [m] & 30.0 & 10.4 & $34.7 \%$ & 11.5 & $38.3 \%$ & 12.7 & $42.3 \%$ & 1.11 & 15 & 27 & 1.8 \\
\hline & & & 23.0 & 8.7 & $37.8 \%$ & 10.4 & $45.2 \%$ & 9.4 & $40.9 \%$ & 1.20 & - & - & - \\
\hline \multirow[t]{2}{*}{ MT2/74 } & $\begin{array}{c}\text { Figs. 10K-M } \\
\text { paratype }\end{array}$ & {$[\mathrm{m}]$} & 30.0 & 9.3 & $31.0 \%$ & 11.1 & $37.0 \%$ & 13.1 & $43.7 \%$ & 1.19 & 13 & 26 & 2.0 \\
\hline & & & 22.0 & 8.2 & $37.3 \%$ & 10.9 & $49.5 \%$ & - & - & 1.33 & - & - & - \\
\hline MT2/101 & $\begin{array}{l}\text { Figs. 10G-J } \\
\text { paratype }\end{array}$ & {$[\mathrm{m}]$} & 28.0 & 9.4 & $33.6 \%$ & 12.1 & $43.2 \%$ & 12.1 & $43.2 \%$ & 1.29 & 17 & 34 & 2.0 \\
\hline MT2/105 & & [m] & 28.0 & 8.4 & $30.0 \%$ & 11.8 & $42.1 \%$ & 11.3 & $40.4 \%$ & 1.40 & 15 & - & - \\
\hline \multirow[t]{2}{*}{ MT2/103 } & $\begin{array}{l}\text { Figs. } 10 D-F \\
\text { paratype }\end{array}$ & {$[\mathrm{m}]$} & 27.0 & 9.1 & $33.7 \%$ & 10.7 & $39.6 \%$ & 11.4 & $42.2 \%$ & 1.18 & 13 & 24 & 1.8 \\
\hline & & & 20.0 & 7.1 & $35.5 \%$ & 9.8 & $49.0 \%$ & 9.5 & $47.5 \%$ & 1.38 & - & - & - \\
\hline MT2/70 & & {$[\mathrm{m}]$} & 27.0 & 8.5 & $31.5 \%$ & 11.6 & $43.0 \%$ & 11.9 & $44.1 \%$ & 1.36 & 13 & 26 & 2.0 \\
\hline
\end{tabular}

